\title{
Overlapping and Sequential Copyright, Patent, and Trademark Protections: A Case for Overruling the Per Se Bar
}

\author{
Loletta Darden*
}

\begin{abstract}
Should extant or expired copyright or patent designs (such as those featuring Mickey Mouse, Wonder Woman, and the Coca-Cola bottle) be eligible for trademark or trade dress protection? Or, should they enter the public domain upon expiration of the copyright or patent without regard for their source-indicating capacity? The law is in conflict on this question. Early Supreme Court precedent imposed a per se bar precluding trademark or trade dress protection for designs of extant or expired copyrights or patents. Yet, later Supreme Court and regional appellate court cases deviated from that precedent, creating conflicting jurisprudence and promoting marketplace conditions that undermine trademark law's purpose and policy of maintaining a fair and ordered marketplace.

Disallowing trademark protection for nonfunctional source-indicating designs because of their current or past copyright or patent status sets up the possibility for consumer confusion, deception, and fraud in the marketplace. This is precisely the type of marketplace disorder that trademark law is designed to prevent. This Article offers normative justifications for the eligibility of copyright or patent protected designs to receive overlapping and sequential trademark protection, as well as a path for resolving the conflicting jurisprudence.

This Article addresses the conflict in overlapping intellectual property protections at the patent/trademark interface and the copyright/trademark interface. At the patent/trademark interface, the per se bar is unnecessary because trademark law's functionality doctrine properly resolves the concerns with overlapping IP rights, as
\end{abstract}

* Associate Clinical Professor of Law at Suffolk University Law School and Director of the Intellectual Property and Entrepreneurship Clinic. I would like to thank my former student, Marcya Betts, now a trademark practitioner, for her assistance in conducting the initial research on this topic and her invaluable assistance proofreading and editing this Article. I am also very appreciative of the feedback received from the members of the Lutie A. Lytle Workshop and Senior Commentators and Fellows of the Thomas Edison Innovation Fellowship sponsored by the Center for the Protection of Intellectual Property, George Mason University Antonin Scalia Law School.

(C) 2021 Darden. This is an open access article distributed under the terms of the Creative Commons Attribution License, which permits unrestricted use, distribution, and reproduction, provided the original author and source are credited. 
functional designs are categorically ineligible for trademark protection. Unfortunately, the Supreme Court and regional appellate courts use different tests for assessing functionality, yielding inconsistent and conflicting results that are impractical in the new economy. This Article proposes a single functionality test that is more comprehensive than the plethora of existing and conflicting tests currently in use. The proposed test assesses a design's use in relation to the product and the design's function in a manner that is less conceptual and more specific to a particular application of the design. At the copyright/trademark interface, the per se bar is also unnecessary for two reasons. First, trademark law's functionality doctrine resolves the conflict for useful articles. A modified version of the functionality test applied to useful articles precludes trademark-ineligible designs from protection. Second, for character designs and music, it is their specific use that would determine their eligibility for trademark protection. Therefore, the proposed use test would examine that specific use to determine whether the design is being used as a source indicator or as an unlawful attempt to extend copyright protection. The proposed tests at the patent/trademark and the copyright/trademark interfaces provide processes for identifying both functional designs and uses of character designs and music that would be ineligible for trademark protection, further demonstrating that a per se bar is unnecessary.

Courts have attempted to ground their reasoning for the per se bar in the copyright and patent law policy that grants the public a right to exploit the subject matter of expired copyrights and patents. This Article posits that trademark law's public policy for maintaining a fair and ordered marketplace preempts the per se bar's public policy of a right to copy, rendering the bar inapplicable in the trademark context. There is a presumption running through current jurisprudence that trademark rights must yield to the public's right to copy, but copyright and patent law are already deemed acceptable incursions on that right. The rules of statutory interpretation, as well as the natural law origin of the right to copy, debunk the presumption that trademark protection must be denied purely because of copyright or patent status. Since there is simply no basis in law or policy for a per se bar of trademark protection, the time has come for Congress or the Court to end the per se bar and resolve the conflict in jurisprudence.

\section{TABLE OF CONTENTS}

Introduction 160

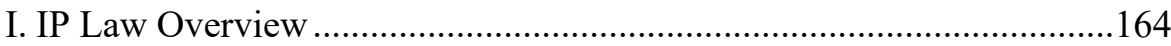

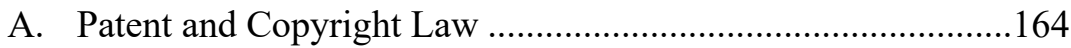

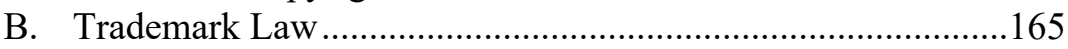

C. Evolution of IP Law.........................................................165

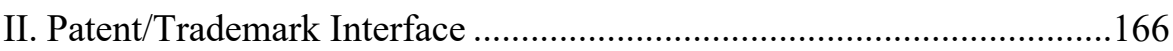

A. Functionality at the Patent/Trademark Interface......................166

1. Supreme Court Cases: Early Precedent .............................167

2. Federal Appeals Court Cases ...........................................171 
3. The Supreme Court's TrafFix Decision.

4. Aesthetic Functionality at the Patent/Trademark Interface 177

B. Distinctiveness at the Design Patent/Trade Dress Interface ....182

III. Proposed Distinctiveness-Functionality Test ........................................183

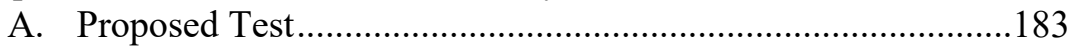

B. Application of the Proposed Test..............................................187

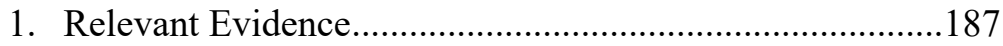

a. Crocs Shoe Design ..................................................187

b. Features Claimed as Trade Dress in the Trademark

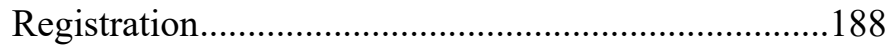

c. Features Claimed in the Design Patent.........................188

d. Statement of Trade Dress Features Made To Secure Registration...............................................................189

2. Applying the Elements of the Proposed Test....................189

a. Distinctiveness or Acquired Distinctiveness ...............189

b. Does the Design Perform a Use or Function? ..............189

c. Is the Design Essential To the Use or Purpose of the Article? ......................................................................190

d. Adverse Effect on the Cost or Quality of the Article ..190

e. Does Advertising Tout the Design's Utilitarian Advantages?

f. Is the Design the Best Design or One of a Few Superior Designs?

g. Does the Proposed Design Present the Design Owner with a Non-Reputation Related Advantage over Competitors?

3. End Result Under the Proposed Test ................................192

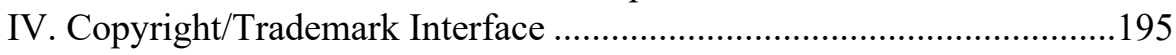

A. Dastar Corp. v. Twentieth Century Fox Film Corp.................195

B. Concerns with Copyright/Trademark Overlap.........................197

V. Proposed Test and Its Application ........................................................199

A. George Gershwin's "Rhapsody in Blue" as a Trademark .......199

B. Comedy III Productions, Inc. v. New Line Cinema: The Three

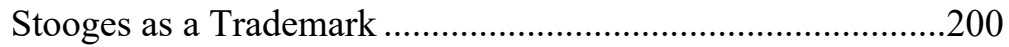

C. Steamboat Willie and Betty Boop as Trademarks ...................200

VI. Statutory Bases for Overlapping and Sequential IP Rights .................204

A. Balancing Conflicting Statutes ..............................................204

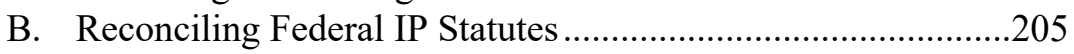

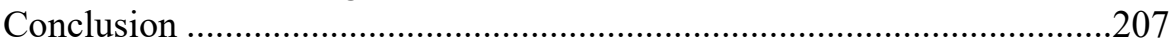




\section{INTRODUCTION}

Should U.S. intellectual property ("IP") law permit companies like Disney and Coca-Cola to claim trademark protection for their iconic designs once copyright and patent protection have expired? ${ }^{1}$ Yes, perhaps, maybe. ${ }^{2}$

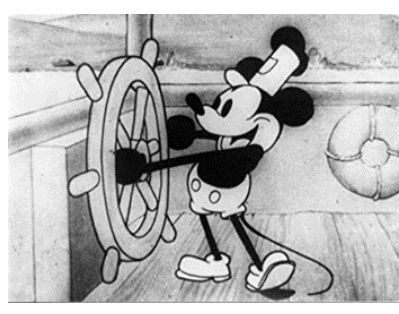

Fig. $1^{3}$

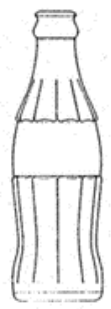

Fig. $3^{5}$

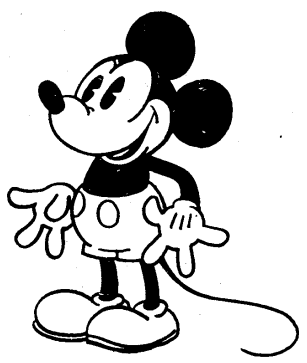

Fig. $2^{4}$

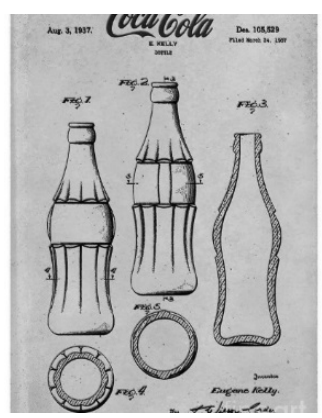

Fig. $4^{6}$

The law is in conflict as to whether such overlapping or sequential trademark rights should apply to the designs shown in Figs. 1-4. Early Supreme Court cases answered this question in the negative by adopting a per se bar precluding extension

1. This Article addresses the lawfulness of overlapping and sequential trademark protection. Questions relating to enforcement and scope of protection are beyond its scope.

2. Disney and DC Comics use the exclusions of both copyright and trademark protection to protect the images of Mickey Mouse, and Batman and Superman, respectively. See Complaint at 13-16, Disney Enters., Inc. v. Lancaster, No. 12-07347 (C.D. Cal. 2012); In re DC Comics, 689 F.2d 1042 (T.T.A.B. 1982).

3. The Steamboat Willie copyright expires January 1, 2024. See Timothy B. Lee, Why Mickey Mouse's 1998 Copyright Extension Probably Won't Happen Again, ARsTeCHNICA (Jan. 8, 2018), https://perma.cc/WPS4-8TJX.

4. U.S. Design Patent No. 82,802 (expired December 16, 1944)

5. U.S. Registration No. 1,057,884 (a three-dimensional configuration of a bottle design for soft drinks, claiming first use in commerce on September 1, 1916).

6. U.S. Design Patent No. D105,529 (expired August 3, 1951). 
of trademark protection to articles of expired patents. ${ }^{7}$ The Court, quoting Merriam v. Holloway Pub. Co. ${ }^{8}$ proceeded under the assumption that a per se bar would also disqualify once-copyright protected designs from trademark protection. ${ }^{9}$ It grounded these per se bars on the policy underlying copyright and patent law: granting the public the "right to copy" and to use the once-patent or -copyright protected thing in the form in which it was protected during the copyright or patent term. ${ }^{10}$ Contrary to the Court's reasoning, however, it is the origin of that very right to copy that supports overruling the per se bars.

The right to copy originated out of the natural law and permitted others to copy freely and without consent any tangible or intangible thing found or placed in the common - the earth and everything in it as produced by the spontaneous hand of nature, including "the fruits it naturally produces, animals that it feeds" and the common knowledge base. ${ }^{11}$ In this Article, I refer to this concept of the common as the Unrestricted Common. For example, under the natural law, gold mineral deposits occurring naturally in the earth belong to no one. The gold mineral forms part of the Unrestricted Common - the public domain. The Unrestricted Common is thus a place where things exist in their natural state or where by operation of law they belong to no one. ${ }^{12}$ If, however, I find gold mineral, dig it up, and put it to use, the mineral no longer belongs to the Unrestricted Common. It becomes my property, provided I have not wasted it or have not left enough for others. All other persons have a duty to leave my mined gold mineral alone. The mined mineral exists in what this Article calls the Restricted Common or marketplace: a place where marketplace order and fairness command a duty of noninterference with another's private right of ownership and control. If, however, I use the mined gold mineral to create a sculpture featuring an original expression of an African princess that I display as a sculpture and use as a base for a line of candelabras, under the natural law others have a duty not to interfere with my enjoyment and use of both the sculpture and the candelabra. But, under the natural law of the Unrestricted Common, my ownership does not prevent others from exercising their right to copy my sculpture and recreate my candelabra. ${ }^{13}$ Marketplace order and fairness demand similar protections for the

7. Singer Mfg. Co. v. June Mfg. Co., 163 U.S. 169 (1896); Kellogg Co. v. Nat'l Biscuit Co., 305 U.S. 111 (1938) (holding that plaintiff did not have exclusive right to a pillow-shaped biscuit, because that was the form made under the patent, patented machines were designed to produce only that form, and a design patent covered the pillow-shaped form; stating that, upon expiration of the patents, the form was "dedicated to the public"). But see TrafFix Devices, Inc. v. Marketing Displays, Inc., 532 U.S. 23 (2001); Bonito Boats, Inc. v. Thunder Craft Boats, Inc., 489 U.S. 141 (1989); Best Lock Corp. v. Schlage Lock Co., 413 F.2d 1195 (C.C.P.A. 1969); Vornado Air Circulation Sys., Inc. v. Duracraft Corp., 58 F.3d 1498 (10th Cir. 1995); Thomas \& Betts Corp. v. Panduit Corp., 138 F.3d 277 (7th Cir. 1998).

8. 43 F. 450,451 (C.C.E.D. Mo. 1890).

9. Singer Mfg. Co., 163 U.S. at 191.

10. Id. at 185 .

11. John Locke, SeCond TREATISE OF Government Ch. $5 \S 26$ (Jonathan Bennett ed., 2017) (1690), https://www.earlymoderntexts.com/assets/pdfs/locke1689a.pdf.

12. Id.

13. See Adam D. Moore, A Lockean Theory of Intellectual Property Revisited, 49 SAN DIEGO L. REV. 1069, 1094 (2012). ("[W]e can view the Lockean model as a bargain between authors and inventors 
creator of the sculpture and candelabra as those accorded the miner of the gold mineral.

While the public enjoys the right to copy anything in the Unrestricted Common, there are times when that right yields to higher public policy purposes - specifically, the exclusions provided under copyright, patent, and trademark law, which are aimed at incentivizing creation and innovation and maintaining marketplace order, and which provide the justification for the Restricted Common. ${ }^{14}$ Without these exclusions under copyright and patent law, there would be little incentive to create, particularly if the creation or innovation could be copied at will with impunity. Similarly, under the trademark law, without restrictions on the use of a mark or a design that serves as a trademark, competitors would be able to use one another's trade symbols to create marketplace disorder through confusion, deception, and fraud. This Article presents normative justifications for overlapping and sequential IP protections as an additional exception to the public's right to copy to preserve marketplace order.

Scholars supporting the per se bar argue that "intellectual property owners should not be permitted to re-categorize one form of intellectual property as another" once the copyright or patent bargain has been struck. ${ }^{15}$ The most commonly held support for the per se bar is the assertion that overlapping or sequential protection extends the duration of copyright or patent protection beyond that which Congress "deemed appropriate for their actual creative efforts."16 Other scholars argue that overlapping and sequential protection (1) interferes with the public's right to copy and freely use the subject matter of expired copyrights or patents, (2) impairs creativity, and (3) presents problems of notice and scope of protection. ${ }^{17}$ However, when the IP rights involved concern two or more IP rights, what is the "actual creative effort" to be assessed ${ }^{18}$ On the other hand, proponents of overlapping and sequential IP rights argue that awarding trademark protection to expired copyright and patent designs is necessary in some instances to preserve a fair and orderly marketplace.

... and society, which reaps the benefits of this innovation. In return for disclosure and, perhaps, fair use, authors and inventors are protected from those who would copy and use intellectual works after being granted access. Without such agreements, those who innovate would likely ... wall off their creations ....").

14. See In re Deister Concentrator Co., 289 F.2d 496, 506 (C.C.P.A. 1961); see also In re Mogen David Wine Corp., 328 F.2d 925 (C.C.P.A. 1964); In re Morton-Norwich Prods., Inc., 671 F.2d 1332 (C.C.P.A. 1982).

15. See Dennis D. Couch, A Trademark Justification for Design Patent Rights 47 (Univ. of Mo. Sch. of L. Legal Stud. Rsch. Paper No. 2010-17), https://perma.cc/RUY3-Y4JA (quoting Chosun Int'l, Inc. v. Chrisha Creations, Ltd., 413 F.3d 324, 328 n.2 (2d Cir. 2005)).

16. Id.

17. See Irene Calboli, Overlapping Copyright and Trademark Protection: A Call for Concern and Action, 2014 ILl. L. ReV. SLIP OPS. 25, 30 (2014); Jeanne C. Fromer \& Mark P. McKenna, Claiming Design, 167 U. PA. L. Rev. 123, 196-97 (2018); Viva R. Moffat, Mutant Copyrights and Backdoor Patents: The Problem of Overlapping Intellectual Property Protection, 19 BERKLEY TECH. L.J. 1473, 1515-16 (2004). This Article address each of these concerns in Parts III and V.

18. Cf. Moffat, supra note 17, at 1514 (noting that "the availability of multiple forms of protection ... makes it impossible to evaluate the incentive that has been provided"). 
This Article argues for overlapping and sequential protections at both the patent/trademark and copyright/trademark interfaces. Part I provides a brief history of the evolution of IP law that has led to overlapping protections. Part II illustrates how the application of a functionality test would have properly decided the issues in Singer Manufacturing, Co. v. June Manufacturing, Co. and Kellogg Co. v. National Biscuit Co. Part II also discusses the evolution of the functionality doctrine among federal appellate courts. Part III proposes a modified functionality test for assessing the eligibility of a patented design for trademark protection.

Moving to the copyright/trademark interface, Part IV discusses trademark protection for useful articles and character designs. In Dastar Corp. v. Twentieth Century Fox Film Corp., the Supreme Court held that trademark rights are not available for subject matter that was once protected by copyright but subsequently entered the public domain, particularly if the trademark action is essentially a substitute for a copyright infringement action. ${ }^{19}$ The Dastar decision is troubling both substantively and technically, as the parts of the opinion frequently cited as its main holding are primarily dicta. Part V proposes a test for assessing when overlapping or sequential trademark protection is appropriate for copyright protected character designs and useful articles.

Part VI debunks, under the principles of statutory interpretation, the presumption undergirding the per se bar: that trademark rights must automatically yield to copyright and patent rights.

Ultimately, this Article offers new rationales for overruling the per se bar and permitting overlapping and sequential trademark protection for the designs of expired or subsisting patents and copyrights. First, the per se bar is overly broad, as the functionality doctrine sufficiently weeds out designs that are categorically ineligible for trademark protection. Second, this Article makes the argument that the public's "right to copy" must yield to trademark protections in some instances to maintain a fair and orderly marketplace. Third, statutory interpretation, which largely has been overlooked in this debate, provides guidance on whether trademark law must indeed yield to copyright and patent policy. The arguments presented in this Article support a normative justification for overruling the per se bar of Singer and Kellogg and implementing the proposed functionality and character design tests to determine the eligibility of once-copyright or -patent protected designs for trademark protection. The time has come for the Supreme Court or Congress to step up and overrule the per se bar of Singer, Kellogg, and Dastar.

19. 539 U.S. 23, 33 (2003). But see Fleischer Studios, Inc. v. A.V.E.L.A., Inc., 636 F.3d 1115 (9th Cir. 2011) (Fleischer Studios I), withdrawn and superseded, 654 F.3d 958, 968 (9th Cir. 2011) (Fleischer Studios II); Comedy III Prods., Inc. v. New Line Cinema, 200 F.3d 593, 595 (9th Cir. 2000). 


\section{IP LAW OVERVIEW ${ }^{20}$}

\section{A. Patent and Copyright Law}

The U.S. Constitution provides the foundation for copyright and patent laws in Article 1, § 8, cl. 8 (the "IP Clause"):

Congress shall have the Power ... To promote the Progress of Science and useful Arts, by securing for limited Times to Authors and Inventors the exclusive Right to their respective Writings and Discoveries. ${ }^{21}$

This clause authorizes Congress to enact laws granting authors and inventors the exclusive right to their creative and inventive works for a limited time as an incentive and reward for making their work public. To delineate a creator's various rights in their works, Congress enacted the patent and copyright statutes.

In the United States, patent protection is available for useful inventions, designs, and plants. This Article addresses utility and design patents only. Utility patents protect the way something functions or its functional advantages. ${ }^{22}$ They apply to machines, processes, articles of manufacture, or compositions of matter. ${ }^{23}$ Design patents protect the way something looks, ${ }^{24}$ covering designs "embodied in or applied to an article of manufacture . . . and not the article itself." 25

Utility and design patent rights exist for a limited time. ${ }^{26}$ Upon expiration of that "limited time," the exclusive right expires, and the work becomes part of the public domain, making it freely available for others to access, copy, and use, unless limited by other statutory protection or a higher policy purpose. ${ }^{27}$

Copyright protects the expression of an original work of authorship, not the article itself. $^{28}$ For example, the copyright for Brenda Joysmith's "Madonna" extends to her artistic rendering of the mother and child, not to the physical object in which it is embodied, and not to all expressions of a mother and child drawing. Rights in copyright attach once the work is fixed or embodied in a medium from which it can

20. In this Article, "IP law" encompasses the U.S. patent, copyright, and trademark laws. This Part does not provide an exhaustive discussion of patent (utility and design), copyright, or trademark law (which would take us well beyond the scope of this Article); instead, it highlights elements of each that are relevant to the question of overlapping or successive rights in IP.

21. U.S. CONST. art. I, $\S 8$, cl. 8.

22. In contrast, trademark laws protect nonfunctional designs that are capable of identifying and distinguishing the source of goods in the marketplace, and copyright protection extends to the expression of nonfunctional designs.

23. 35 U.S.C. $\$ 101$

24. See $i d . \S \S 101,171$.

25. MANUAL OF PATent EXAmination Procedure $§ 1502$ (2019); see also id. § 1502.01. The Supreme Court has defined an article of manufacture as "a thing made by hand or machine." Samsung Elecs. Co. v. Apple Inc., 137 S. Ct. 429, 435 (2016).

26. The term of a utility patent is twenty years from the date of filing (or the earliest effective filing date), and for design patents the term is fifteen years measured from the date of issuance.

27. Maintaining and preserving a fair and ordered common (marketplace) may be a qualifying higher purpose affecting the public's right to copy.

28. 17 U.S.C. $\S 102(b)$. 
be perceived, and they last at least for the life of the author plus seventy years after the author's death. ${ }^{29}$

\section{B. Trademark LaW}

Trademark law does not arise from a direct constitutional mandate, but Congress finds its authority to promulgate federal trademark law in the Commerce Clause of the U.S. Constitution. ${ }^{30}$ Unlike patent and copyright law, trademark law does not concern the creation of original or innovative products; instead, it focuses on maintaining a fair and orderly marketplace for competition by protecting trade symbols used in selling or offering goods or services in commerce. A category of trademark law is trade dress, which will be the focus of this Article. Trade dress is another name for trademark protection for designs. ${ }^{31}$

One goal of trademark law is to prevent marketplace disorder resulting from the use of confusingly similar trade symbols that cause confusion, deception, mistake, and fraud in the marketplace. ${ }^{32}$ Trademark rights last indefinitely, as long as the mark is used in commerce in the ordinary course of trade. It is the indefiniteness of trademark protection that many scholars contend warrants barring trademark protection for designs or things that have enjoyed a definite term of exclusivity under either copyright or patent law. This concern will be addressed further below. ${ }^{33}$

\section{Evolution of IP LAW}

When Congress first enacted the various IP laws, there were clear demarcations identifying the subject matter protectable under patent, copyright, and trademark. ${ }^{34}$

29. U.S. COPYRIght OFF., Circular 15A: Duration OF COPYRight (2011), https://perma.cc/48N9-AZ2X. For works made for hire or anonymous works, "the duration of copyright is 95 years from first publication or 120 years from creation, whichever is shorter." Id.

30. U.S. CONST. art. I, § 8, cl. 3.

31. See John H. Garland Co. v. Clarke Checks, Inc., 711 F.2d 966, 980 (11th Cir. 1983). Examples of trade dress include product configurations (Pepperidge Farm Goldfish, the three-dimensional shape of the Hershey's Kiss, the Crocs shoe design); product packaging (Tea Forté pyramidal shaped box); interior/exterior store designs, which are treated like packaging (Apple Store interior and exterior designs); and uniforms (Chippendales, UPS).

32. The marketplace is defined as the place where consumers do business, purchase goods, and otherwise engage in commerce. See supra note 27 and accompanying text. See also Qualitex Co v. Jacobson Prods. Co., 514 U.S. 159, 163-64 (1995) (discussing purpose of trademark law).

33. See infra Part II.

34. Congress passed the first Patent Act covering utility patents in 1790, Patent Act of 1790, Ch. 7, 1 Stat. 109-12 (protection extended to an article's utility, usefulness, or functionality); the first Design Patent Act in 1842, Act of Aug. 29, 1842, Ch. 263, § 3, 5 Stat. 543, 543-44) (protection extend to the designs of specifically identified types of articles); and the first Copyright Act in 1790, Copyright Act of 1790, 1 Stat. 124 (protection extended to an author's artistic or creative intellectual expression for a very limited category of articles). Congress enacted the first Trademark Act in 1870, which the Supreme Court declared unconstitutional in 1879. See In re Trade-Mark Cases, 100 U.S. 82, 98 (1879). Congress then enacted the Trademark Act of 1881, based on its Commerce Clause powers. Act of Mar. 3, 1881, Ch. 138, § 1-13 Stat. 502. The 1881 Act "provided for registration of trademarks used in commerce with foreign nations, or with the Indian tribes." Id. Given the limited value of the law, Congress later abolished 
Those boundaries began to erode with amendments to the Design Patent and Copyright Acts. The first Design Patent Act, passed in 1842, protected the ornamental shape of an article of manufacture, as well as fabric designs, busts or statues, and design impressions to be placed on an article. ${ }^{35}$ The 1902 amendments expanded allowable subject matter to "any new, original, and ornamental design for an article of manufacture." ${ }^{36}$ Similarly, the original Copyright Act granted protection to authors of books, charts, and maps, ${ }^{37}$ but in 1909, Congress expanded the Copyright Act to include "all the writings of an author." 38 The original Trademark Act protected symbols and devices adopted and used to distinguish the goods or property of the trademark owner, allowing the trademark owner exclusive use of the mark in commerce. ${ }^{39}$ After passage of the Lanham Act, courts interpreted "devices" to include product designs and configurations. ${ }^{40}$ As a result, a design for an article of manufacture or the expressive design of a three-dimensional article qualified, in some instances, as a "device" under the trademark law. This Article explores the overlap at both the patent/trademark and copyright/trademark interfaces. ${ }^{41}$

\section{PATENT/TRADEMARK INTERFACE}

\section{A. Functionality at the Patent/Trademark Interface}

At the patent/trademark interface, early Supreme Court cases, specifically the Singer ${ }^{42}$ and Kellogg ${ }^{43}$ cases, suggested a rigid siloing between patent and trademark protection by virtue of a per se bar precluding overlapping or sequential trademark protection for patent protected designs; however, as recognized by more recent court decisions, such a per se bar is unnecessary. For example, Supreme Court decisions that occurred after enactment of the Lanham Act, as well as those of many lower courts, have declined to follow the Court's per se bar in favor of a functionality test to determine trademark eligibility. As will be discussed below, the Court developed a particular test for functionality that it applies in cases involving once-patent protected designs for which trademark protection is sought. Although the Court created a test to assess functionality in these instances, it did not overrule the per se bar of Singer and Kellogg. As a result, the Court of Customs and Patent Appeals, as well as other federal regional appellate courts, have imposed their own clarification of Singer and Kellogg and adopted their own analysis for assessing functionality.

\footnotetext{
it, replacing it with the 1905 Act, 15 U.S.C. $\$ 1051$ et seq., which Congress amended in 1946. The 1946 Act, known as the Lanham Act, is the law governing current U.S. trademark law, as amended in 1996. 
The following cases show the evolution of the per se bar and the how subsequent courts have implicitly overruled it in part by developing a functionality test to assess whether a once-patented design is eligible for trademark protection.

\section{Supreme Court Cases: Early Precedent}

In Singer and Kellogg, two early Supreme Court cases decided in 1896 and 1938, respectively, the Court announced a per se rule barring the extension of trademark protection to any article or name of an article claimed or disclosed in a patent or used by the patentee during the life of the patent. ${ }^{44}$ Justification for the per se bar, the Court reasoned, emanates from patent law policy declaiming the subject matter of expired patents to be public property, which any person has the unfettered right to use or practice. ${ }^{45}$ In Singer, over 100 existing and expired patents dictated the look and operation of the sewing machines, ${ }^{46}$ so the Court imposed a per se bar denying trade dress protection for the sewing machine design ostensibly based on patent policy. In Kellogg, the Court followed its Singer decision and imposed a per se bar on the pillow-shaped cereal design, since that design had been covered by a design patent, ${ }^{47}$ and several expired utility patents that covered a machine and a process for making the pillow-shaped product. ${ }^{48}$

A superficial reading of the Court's holdings in these cases leads to an incorrect conclusion that the Court denied trade dress protection based entirely on the patent policy granting the public the right to copy designs of expired patents. In reality, the underlying basis for the Court's denial of trade dress protection in both cases was the functionality of the designs at issue, not a per se bar based on patent policy. Understanding the Court's actual basis for denial of trademark (trade dress) protection shifts the focus of the inquiry in these cases from a "right to copy" to a "need to copy" analysis. Functionality assesses a need to copy based on competitive

44. This Article addresses the designs at issue in each of these cases. See Singer, 163 U.S. at 185 ("[A]long with the public ownership of the device there must also necessarily pass to the public the generic designation of the thing which has arisen during the monopoly in consequence of the designation having been acquiesced in by the owner, either tacitly, by accepting the benefits of the monopoly, or expressly by his having so connected the name with the machine as to lend countenance to the resulting dedication."); Kellogg, 305 U.S. at 120 ("Where an article may be manufactured by all, a particular manufacturer can no more assert exclusive rights in a form in which the public has become accustomed to see the article and which, in the minds of the public, is primarily associated with the article rather than a particular producer, than it can in the case of a name with similar connections in the public mind.").

45. See Karl A. Limbach, Practice of Expired Patents, 8 W. RSRV. L. REV. 183, 184 (1957).

46. Some of the more important patents included: a patent to Elias Howe, issued September 10, 1846 , which remained in force until 1867, covering the use of the eye-pointed needle in combination with a shuttle and automatic feed; a patent to John Bachelder, issued in 1849, which remained in force until about 1877, covering the principle of a continuous feed; and a patent to Allen B. Wilson, issued in 1851, for a feeding bar, extending patent coverage of the sewing machine component through 1872. See Singer, 163 U.S. at 172 (Synopsis). When the Bachelder patent expired, competitors began copying the design and function of the Singer Company machines. Id. at 174.

47. The district court declared the design patent invalid in 1908 because the design had been publicly disclosed two years before the filing of the patent application. See Kellogg, 305 U.S. at 119 n.4.

48. Id. at 119-20. 
necessity, not a per se bar based on patent policy, and is grounded in the right of other providers of goods and services to compete effectively in the marketplace.

The "right to compete effectively" is the heart of the functionality doctrine ${ }^{49}$ The law protects this competitive need by permitting others to copy a design that provides a functional advantage needed to compete in the relevant product market. ${ }^{50}$ Professor Mark McKenna explains that courts generally see utilitarian functionality as having two different purposes: "(1) as a mechanism for insuring access to competitively necessary product features; and (2) as a means of channeling protection of certain features exclusively to patent law." ${ }^{\text {"1 }}$ Elements supporting factor one of McKenna's two-part categorization are clear in the Kellogg analysis.

In Kellogg, the pillow shape was the most efficient design for its particular type of cereal. Any other shape would have increased manufacturing costs and resulted in lower product quality. The design provided National Biscuit Company with a utilitarian advantage that competitors needed in order to compete effectively. Likewise, in Singer, the patented elements dictated the shape of the machine. They gave the sewing machines functional advantages competitors needed to copy to compete effectively. In each case, the disputed design elements were necessary for effective competition. Consistent with McKenna's factor one, the factual circumstances in both cases supported barring trademark protection based on functionality - a need to copy. ${ }^{52}$ The per se bar was unnecessary and overbroad.

The Court's holdings in Singer and Kellogg are also consistent with both the first Restatement of Torts and the third Restatement of Unfair Competition definitions of functionality. The first Restatement of Torts declares a design to be functional if it affects the "purpose, action or performance, or the facility or economy of processing, handling or using" the product. ${ }^{53}$ The third Restatement of Unfair Competition defines a functional feature as one that "affords benefits in the manufacturing, marketing, or use of the goods or services with which the design is used ... that are important to effective competition by others and that are not practically available through the use of alternative designs." ${ }^{\text {5 }}$ As discussed above, the Court found each of these factors present in both cases. Although the Court labeled its decision a per

49. See Sandra L. Rierson, Toward a More Coherent Doctrine of Trademark Genericism and Functionality: Focusing on Fair Competition, 27 Fordham InTELL. Prop. MEdia \& ENT. L.J. 691, 712 (2017). Later iterations of the functionality doctrine have been expanded to a twofold test which considers whether the design feature either (1) is "essential to the use or purpose," or (2) "affects the cost or quality" of the product at issue. See TrafFix Devices, Inc. v. Marketing Displays, Inc., 532 U.S. 23, 32-33 (2001).

50. The use of alternate shapes would put competitors at a non-reputational disadvantage due to increased manufacturing costs and decreased product quality. See Qualitex Co. v. Jacobson Prods. Co. 514 U.S. 159, 165 (1995) (citing Inwood Lab'ys, Inc. v. Ives Lab'ys, Inc., 456 U.S. 844, 850 n. 10 (1982)).

51. Mark McKenna, (DYS)Functionality, 48 HOUSTON L. REV. 823, 824 (2011) [hereinafter McKenna, (DYS)Functionality]. For discussion of another form of functionality, known as "aesthetic functionality," see $i d$. at $843-58$.

52. Id.

53. RESTATEMENT (FIRST) OF TORTS $\S 742$ (AM. L. INST. 1938). While the Court set forth a different test for functionality in TrafFix, the product design in question would have maintained their functionality under the TrafFix test. See TrafFix, 532 U.S. at 32-33.

54. ReSTATEMENT (THIRD) OF UNFAIR COMPETITION $§ 17$ (AM. L. INST. 1995). 
se rule of exclusion based on patent policy's right to copy, ${ }^{55}$ the evidence underlying the Court's reasoning points to functionality as the dispositive consideration in both opinions.

The Court's analyses and evidentiary considerations in both Singer and Kellogg fit squarely within the functionality (need to copy) doctrine, not a per se right to copy doctrine. The old adage, "if it walks like a duck and talks like a duck ..." applies to Singer and Kellogg. Labels matter. It is important to properly characterize the Court's decisions as what they are - refusals based on the functionality doctrine, not a sweeping per se bar. A per se bar forecloses the possibility of trade dress protection for all designs, functional or nonfunctional, that are currently or were formerly claimed or disclosed by a patent, whereas a functionality preclusion leaves open the possibility of trade dress protection for patented designs that are not considered functional under trademark law.

According to the Constitution's IP Clause, functional designs fall under the exclusive purview of the patent law. The clause states that Congress shall have the power "to promote the progress of ... [the] useful Arts by securing for limited Times to ... Inventors the exclusive Right to their ... discoveries."56 "Useful" is synonymous with functional (utilitarian) technological innovation. ${ }^{57}$ Because, for such non-expressive works, the IP Clause does not apply to non-useful or nonfunctional designs, there is no constitutional reason for excluding such designs from trademark protection, even if they were disclosed in a patent. Force-fitting these nonfunctional designs into the ambit of the IP Clause improperly disregards the "useful" limitation. ${ }^{58}$ Yet, some scholars continue to argue that Singer and Kellogg affirm the public's right to copy. ${ }^{59}$ Not true. These cases merely point out that currently or formerly patent protected designs that are functional may not receive

55. Patent policy requires that at the end of the patent term the patented inventions become part of the public domain and are available for copying by anyone. This is part of the patent bargain. However, the patent bargain runs to those things for which patent protection was granted, not those elements that were merely disclosed in a patent but are covered by another form of protection that precludes copying.

56. U.S. CONST. art. I, $\S 8$, cl. 8 (emphasis added).

57. See Mark P. McKenna \& Christopher Jon Sprigman, What's In, and What's Out: How IP's Boundary Rules Shape Innovation, 30 HARV. J.L. \& TECH. 491, 504 \& n.46 (2017). Footnote 46 reads: "See, e.g., John R. Thomas, The Patenting of the Liberal Professions, 40 B.C. L. REV. 1139, 1140 (1999) ... (describing the Patent Act's subject matter categories as 'embodying the current understanding' of the useful arts 'to mean the technological arts'); David J. Kappos, John R. Thomas, \& Randall Bluestone, $A$ Technological Contribution Requirement for Patentable Subject Matter: Supreme Court Precedent and Policy, 6 Northwestern J. TeCh. \& InTEll. Prop. 152, 153 (2008) (connecting the 'useful Arts' with technological innovation specifically and arguing that, in our constitutional context, 'patentable advances must be tied to a particular machine or apparatus, or alternatively, must reside in the physical transformation of an article to a 'different state or thing.')." Id.

58. U.S. CONST. art. I, $\S 8$, cl. 8 .

59. Perry J. Saidman, Kan TrafFix Kops Katch the Karavan Kopy Kats? Or Beyond Functionality: Design Patents Are the Key To Unlocking the Trade Dress/Patent Conundrum, 82 J. PAT. \& TRADEMARK OFF. SOC'Y 839, 849 (2000) ("[T]he Supreme Court has clearly recognized the public's 'right to copy' the subject matter of expired patents."); see also Thomas F. Cotter, Is This Conflict Really Necessary? Resolving an Ostensible Conflict Between Patent Law and Federal Trademark Law, 3 MARQ. INTELL. PROP. L. REV. 25, 26-27 nn.6-7 (1999). 
trademark protection. ${ }^{60}$ This understanding is reflected in more recent jurisprudence; despite the Singer and Kellogg precedent, lower courts over the last few decades have begun to rely on functionality as a basis for denying trademark protection for functional designs claimed or disclosed in patent documents, instead of the per se bar of Singer and Kellogg. ${ }^{61}$ The Court of Customs and Patent Appeals (CCPA) was quite active in developing the case law on this issue, which challenged then, and continues to challenge today, the Court's reasoning on for a per se bar. ${ }^{62}$

60. The Court's decision in Compco Corp. v. Day-Brite Lighting, Inc., 376 U.S. 234, 238 (1964), and its later clarification of the Compco holding in Bonito Boats, Inc. v. Thunder Craft Boats, Inc., 489 U.S. 141 (1989), may have been the events that kicked the door open for finding nonfunctional designs, whether patented or unpatented, eligible for trademark protection. To understand the Compco holding, an understanding of its companion case, Sears, Roebuck \& Co. v. Stiffel Co., 376 U.S. 225 (1964), is necessary. In Sears, the Court held that state unfair competition law could not prevent Sears from slavishly copying Stiffel's unpatented pole lamp design. Sears, 376 U.S. at 231. The Court reasoned that "[a]n unpatentable article, like an article on which the patent has expired, is in the public domain and may be made and sold by whoever chooses to do so." Id. In these situations, state courts could only impose labeling or other similar measures to prevent consumer confusion but could not enjoin copying. See id. at 231-33. In Compco, although the Court followed its Sears holding, it introduced a single word, "other," which fundamentally altered application of the per se bar of trade dress protection for subject matter of extant or expired patents. Compco, 376 U.S. at 238. The Court held that if a design is not protected by design patent or other federal statutory protection, it could be copied at will. Id. (emphasis added). So, what does "other" include? Trademark protection is "other" statutory protection. In Bonito Boats, the Court raised nonfunctionality as a basis for withholding application of the per se bar. See Bonito Boats, 489 U.S. at 157-58 ("With some notable exceptions, including the interpretation of the Illinois law of unfair competition at issue in Sears and Compco ... the common-law tort of unfair competition has been limited to protection against copying of nonfunctional aspects of consumer products which have acquired secondary meaning such that they operate as a designation of source."). Based on this statement, one could infer that "other" as referred to in Compco refers to trademark Law.

61. See Sunbeam Prods., Inc. v. West Bend Co., 123 F.3d 246 (5th Cir. 1997) (having adopted the "utilitarian" standard of functionality that focuses on the protection of competition, holding that trade dress protection was not foreclosed despite prior patent protection); Thomas \& Betts Corp. v. Panduit Corp., 138 F.3d 277 (7th Cir. 1998) (reasoning, under a competition model of functionality, that functionality prevents an impermissible extension of patent protection by trademark; and since T \& B's cable tie components (i.e., the locking mechanism, tail, etc.) did not drive or dictate the design of the ovalshaped head, deeming the design nonfunctional); Best Lock Corp. v. Schlage Lock Co., 413 F.2d 1195 (C.C.P.A. 1969) (denying trade dress protection where utility patent explicitly disclosed the functional advantages of the figure-8 lock configuration); Vornado Air Circulation Sys., Inc. v. Duracraft Corp., 58 F.3d 1498, 1500 (10th Cir. 1995) ("Where a product configuration is a significant inventive component of an invention covered by a utility patent ... it cannot receive trade dress protection ...."); see also Moldex-Metric, Inc. v. McKeon Prods., Inc., 891 F.3d 878, 881-82, 884-85 (2018) (defining a product's functional features as "features which constitute the actual benefit that the consumer wishes to purchase"; noting that "alternative designs ... may indicate whether the trademark itself embodies functional or merely ornamental aspects of the product"); Nora Beverages, Inc. v. Perrier Grp. of Am., Inc., 269 F.3d 114, 120 n.4 (2d Cir. 2001) (not following Morton-Norwich; noting that the Supreme Court's rulings in Qualitex and TrafFix "expand[ed] the functionality doctrine" and that designs that are "useful" are functional and ineligible for trademark protection).

62. See, e.g., Best Lock Corp., 413 F.2d at 1199-1200; In re Mogen David Wine Corp., 328 F.2d 925, 933 (C.C.P.A. 1964) (Rich, J., concurring); In re Morton-Norwich Prods., Inc., 671 F.2d 1332 (C.C.P.A. 1982); Valu Eng'g, Inc. v. Rexnord Corp., 278 F.3d 1268 (Fed. Cir. 2002); cf. In re Deister Concentrator Co., 289 F.2d 496, 502 (C.C.P.A. 1961). 


\section{Federal Appeals Court Cases}

The underlying basis for the CCPA's decision to award trade dress protection to some designs of existing or expired design or utility patents was functionality, but specifically functionality assessed from the perspective of competitive impact. The court's reasoning was that "'functionality' is determined in light of 'utility,' which is determined in light of 'superiority of design,' and rests upon the foundation [that the feature is] 'essential to effective competition." "63 The "competitive need" test is predicated upon maintaining marketplace order and preventing consumer confusion. ${ }^{64}$

From this perspective, the locus of the inquiry should consider competitive need, that is, a need to copy rather than a right to copy. To that point, evidence useful in determining whether a particular design is "superior" includes utility patents that disclose the functional advantage(s) of the design ${ }^{65}$ and advertising touting the utilitarian advantages of the design. ${ }^{66}$ And since competition "is really the crux of the matter," an important consideration should be the availability of alternative designs. ${ }^{67}$ The court applied these considerations to designs claimed in both design and utility patents. ${ }^{68}$

In a 1964 case, In re Mogen David Wine Corp., the CCPA found the applicant's distinctive and novel design for a wine decanter to be nonfunctional, and held that the existence of a design patent did not require a contrary finding. ${ }^{69}$ Subsequently, in a 1982 case, In re Morton-Norwich Products, Inc. ${ }^{70}$ the CCPA refined its functionality test to balance the "right to compete through imitation" against a trademark owner's right to prevent infringement of its established trade symbols. ${ }^{71}$ In refining its functionality test to accommodate this balance, the court gave consideration to the design's (1) utility, (2) superiority, and (3) necessity for effective competition. ${ }^{72}$ With regard to the third factor, the court equated the necessity of the design for competition with the "right to compete," which it related to the "need to

63. Morton-Norwich, 671 F.2d at 1340 (quoting Ives Lab'ys, Inc. v. Darby Drug Co., 601 F.2d 631, 643 (2d Cir. 1979)).

64. See Qualitex Co. v. Jacobson Prods. Co., 514 U.S. 159 (1995); Mogen David, 328 F.2d at 933 (Rich, J., concurring).

65. See Morton-Norwich, 671 F.2d at 1340-41 (citing Best Lock Corp., 413 F.2d at 1199; Mine Safety Appliances Co. v. Storage Battery Co., 405 F.2d 901, 902 (C.C.P.A. 1969); Deister, 289 F.2d at 501; Daniel v. Electric Hose \& Rubber Co., 231 F. 827, 833 (3d Cir. 1916)).

66. See In re Shenango Ceramics, Inc., 362 F.2d 287, 291 (C.C.P.A. 1966).

67. Morton-Norwich, 671 F.2d at 1341.

68. See id.; see also Mogen David, 328 F.2d at 932; Best Lock Corp., 413 F.2d at 1195.

69. 328 F.2d at $930,932-33$ (Rich, J., concurring).

70. 671 F.2d at 1332 .

71. Id. at 1337.

72. Id. at 1340 . The party asserting trademark rights bears the burden of proving the design nonfunctional. Id. at 1343 . The existence of a utility patent is evidence of functionality but is not conclusive of the issue. Id. at 1340-41. More recently, the Supreme Court in TrafFix held that a utility patent has "vital significance" to a functionality determination and the boundary between registrable and non-registrable trade dress. TrafFix Devices, Inc. v. Marketing Displays, Inc., 532 U.S. 23, 29 (2001) See also McKenna \& Sprigman, supra note 57, at 528-30 (discussing TrafFix and lower court application of the TrafFix functionality test). 
copy" in order to compete effectively. ${ }^{73}$ The competitive impact of a design often turns on the existence of alternative designs. ${ }^{74}$ Using its three-factor inquiry, the court found the bottle design in Morton-Norwich to be nonfunctional, particularly because it was not "the best or one of a few superior designs available." 75

Fundamental to the CCPA's reasoning was the belief that a "feature dictated solely by 'functional' (utilitarian) considerations may not be protected as a trademark." 76 Only nonfunctional articles, as contemplated by the 1946 amendments to the Lanham Act, may be protected as a trademark. ${ }^{77}$ As interpreted by the CCPA, a design could be classified as "nonfunctional" if alternative functionally equivalent designs exist. Under the CCPA's reasoning, if a feature is functional, removing that feature from public use indefinitely would adversely impact competition, meaning competitors would be placed at a competitive disadvantage by their exclusion from using the protected device. The CCPA's functionality doctrine was significant because it was the first to consider marketplace impact, an analysis that honors the purpose of trademark law: promoting competition and preserving a fair and ordered marketplace. More specifically, the CCPA's test promotes an ordered marketplace free of confusingly similar designs resulting in consumer confusion, deception, fraud, or mistake. Mogen David and Morton-Norwich helpfully illustrate the contours of the CCPA test.

In both Mogen David and Morton-Norwich, the heart of the conflict was the same as that presented in Singer and Kellogg - whether prior or existing patent protection precludes subsequent trademark protection for those designs claimed or disclosed in a patent. In both his majority opinion in Morton-Norwich and his concurring opinion in Mogen David, Judge Rich focused the question on whether the designs at issue were functional. ${ }^{78} \mathrm{He}$ noted that "[a]n exception to the right to copy exists ... where the product or package design under consideration is 'nonfunctional' and serves to identify its manufacturer or seller."79 This exception exists because, as Judge Rich intimated in Mogen David, in certain circumstances the right to copy yields to the higher public policy purpose of preventing confusion in the marketplace. In his concurring opinion in Mogen David, Judge Rich agreed with the court that the public enjoys a right to copy once-patent or -copyright protected designs, but in certain circumstances that right yields to the higher public policy purpose of preventing

73. Morton-Norwich, 671 F.2d at 1339. Almost twenty years after Morton-Norwich, the Court defined a functional feature as one "essential to the use or purpose" of the article or that "affects [its] cost or quality." TrafFix, 532 U.S. at 33. The Court further held that the existence of alternative designs does not affect a functionality determination. Id. at 34 .

74. Morton-Norwich, 671 F.2d at 1341.

75. Id. at 1341-42. The court considered four factors in assessing functionality: (1) whether a utility patent discloses the utilitarian advantage of the design; (2) whether advertising refers to the design as utilitarian; (3) whether functionally equivalent alternative designs are available to competitors; and (4) whether the design is a result of a comparatively simple or cheap method of manufacturing. Id. at 134041.

76. Best Lock Corp., 413 F.2d at 1199.

77. Id.

78. Morton-Norwich, 671 F.2d at 1335; In re Mogen David Wine Corp., 328 F.2d 925, 932 (C.C.P.A. 1964) (Rich, J., concurring).

79. Morton-Norwich, 671 F.2d at 1337. 
confusion in the marketplace. ${ }^{80}$ Judge Rich's concurrence in Mogen David became the majority in Morton-Norwich, and the Federal Circuit continues to follow his reasoning today.

Judge Rich, in In re Deister Concentrator Co., placed the origin of the right to copy in the general law. ${ }^{81}$ By definition, the general law includes the common law, which assimilated the principles of the natural law, making this right's starting point the natural law. ${ }^{82}$ One recognized limitation on the natural law right to copy is the preservation of an orderly and peaceful common (marketplace). ${ }^{83}$ The positive law, enacted to preserve order and peace in the marketplace, attempted "to balance the rights of property owners with the rights of others to use their property industriously." 84 Purposefully allowing public confusion, deception, fraud, or mistake runs counter to the underlying aims of the natural law, and the obligations of government under the positive law to preserve a fair and ordered marketplace. ${ }^{85}$ The per se bar introduces marketplace disorder because it permits multiple users of the same source-identifying design in commerce, which adversely impacts the consumer shopping experience. ${ }^{86}$ Trademarks preserve order by keeping the marketplace free from confusion, mistake, and deception, and warrant an exception under the right to copy consistent with that afforded to patents and copyrights.

Judge Rich recognized the copyright and patent laws as creating a temporary incursion on the public's right to copy in order to incentivize creation and innovation. An incursion on the right to copy is also warranted under trademark law policy and is necessary to preserve a fair and ordered marketplace consistent with the natural law origins of the right to copy upon which the per se bar is based. A per se bar contradicts trademark law's purpose of creating a fair and ordered marketplace free of confusion resulting from confusingly similar trademarks and trade dress. ${ }^{87}$ Judge Rich correctly expressed the notion that the public's right to copy yields to the copyright and patent laws, as this is necessary to accomplish the purpose of those laws. ${ }^{88}$ By extension, the public's right to copy should yield to trademark law

\footnotetext{
80. Mogen David, 328 F.2d at 933 (Rich, J., concurring).

81. 289 F.2d 496, 501 n.3 (C.C.P.A. 1961).

82. See generally John C. H. Wu, The Natural Law and Our Common Law, 23 FORDHAM L. REV. 13 (1954); James R. Stoner, Jr., Common Law and the Law of Reason, WiTHERSPOON INST. (2011), https://perma.cc/93VX-37LY; Mike Rappaport, Some Examples of the General Common Law, L. \& LIBERTY (Aug. 14, 2015), https://perma.cc/US5R-3VLN.

83. LOCKE, supra note 11 , at Ch. $9 \S 131$.

84. Mark P. McKenna, The Normative Foundations of Trademark Law, 82 NOTRE DAME L. REV. 1839, 1875 (2007); see also Eric R. Claeys, Takings, Regulations, and Natural Property Rights, 88 CORNELL L. REV. 1549, 1556 (2003) ("[E]very owner is entitled to some zone of non-interference in which to use her possessions industriously, productively, and consistent with the health, safety, property, and moral needs of her neighbors."). A duty of the positive law is the preservation of property. LOCKE, supra note 11 , at Ch. $7 \S 88$, Ch. $9 \S 124$.

85. LOCKE, supra note 11 , at Ch. $5 \S 34$.

86. See Thomas R. Lee, Glenn L. Christensen \& Eric D. DeRosia, Trademarks, Consumer Psychology, and the Sophisticated Consumer, 57 EMORY L.J. 575, 583 (2008).

87. See supra note 64 and accompanying text.

88. In re Mogen David Wine Corp., 328 F.2d 925, 933 (C.C.P.A. 1964) (Rich, J., concurring) (in some instances the public's right to copy yields to trademark law); cf. In re Deister Concentrator Co., 289 F.2d 496, 506 (C.C.P.A. 1961).
} 
because failing to do so harms the marketplace by depriving businesses of property and creating chaos in the marketplace. ${ }^{89}$

Some circuit courts followed the CCPA and began to assess functionality under the competitive need test rather than imposing the per se bar that Singer and Kellogg ostensibly require; however, other courts developed their own variations of the functionality test, resulting in conflicting standards. ${ }^{90}$ In light of this circuit variation, the Supreme Court decided to weigh in on the functionality debate in TrafFix Devices, Inc. v. Marketing Displays, Inc. ${ }^{91}$

\section{The Supreme Court's TrafFix Decision}

TrafFix, decided by the Supreme Court in 2001, involved trade dress protection for temporary road signs that were the subject of expired utility patents. ${ }^{92}$ The hope by trademark practitioners was that the Court would announce a uniform standard for determining functionality and addressing the impact prior utility patent protection should have on that determination. While the Court ruled that prior or existing utility patent protection presents "strong evidence" of functionality-a necessary implication being that such protection is not an outright per se bar" ${ }^{93}$-it failed to bring uniformity to the functionality determination.

The TrafFix Court merely reaffirmed its prior Inwood standard for utilitarian functionality; the Inwood test characterizes a functional product feature as one that is "essential to the use or purpose" or "affects the cost or quality" of an article. ${ }^{94}$ The Court did not provide any guidance on what "essential to the use or purpose" or "affects the cost or quality" means or what evidence should be considered in making these determinations. ${ }^{95}$ In an earlier case, Qualitex, the Court had focused on the Inwood test from a competitive need perspective, holding that "essential to the use or purpose" or "affects the cost or quality" points to a feature whose exclusive use would "put competitors at a significant non-reputation-related disadvantage." However, the TrafFix Court stated that the "non-reputation-related disadvantage" language applies only to aesthetic functionality, not utilitarian functionality ${ }^{97} \mathrm{By}$ this characterization, the Court recommitted to the Inwood rule for questions of

\footnotetext{
89. See LOCKE, supra note 11 , at Ch. 5 .

90. See supra note 61 and accompanying text.

91. 532 U.S. 23 (2001).

92. Id. at 26. Marketing Displays, Inc. ("MDI") owned two utility patents claiming the dual-spring technology used to keep the signs upright, and it incorporated the once patented features into its road signs. After the patents expired, TrafFix began selling road signs that included the dual-spring design. In creating its signs, TrafFix reverse-engineered the MDI sign. Id. at 25-26.

93. Id. at 29-30. The party asserting trade dress rights bears the burden of proving the trade dress to be nonfunctional. Finding the dual-spring design functional, the Court denied trade dress protection. Id.

94. Id. at 35 (quoting Inwood Lab’ys, Inc. v. Ives Lab'ys, Inc., 456 U.S. 844, 850 n. 10 (1982)).

95. See Moldex-Metric, Inc. v. McKeon Prods., Inc., 891 F.3d 878, 886 (9th Cir. 2018) ("In Inwood and TrafFix, the Supreme Court did not explain what it takes for a feature to be 'essential to the use or purpose of a product."').

96. Qualitex Co. v. Jacobson Prods. Co., 514 U.S. 159, 165 (1995).

97. TrafFix, 523 U.S. at 33.
} 
utilitarian functionality without adopting the Qualitex qualification regarding competitive effect. In essence, the Court's TrafFix reasoning distinguished its newly articulated test from the competitive need test. Professor Mark Thurmon writes that by reaffirming the Inwood rule, the TrafFix Court "turned its back on the [functionality] doctrine's rich history, recast its own prior functionality decisions, and adopted new rules that no one seems to understand." ${ }^{.98}$

The problem with the Court's Inwood/TrafFix test is that it is subject to multiple interpretations. On one hand, the first element of the Inwood/TrafFix test, "essential to use or purpose," could be equated to the competitive need test. Professor Margreth Barrett intimates that this interpretation would take advantage of a rich body of case law directing the evidentiary inquiry, with adjustments needed to accommodate the Court's direction from TrafFix regarding how to factor the existence of a patent into the overall analysis. ${ }^{99}$ This interpretation would also respect trademark law and policy by considering marketplace impact and giving probative weight to the existence of alternative designs that perform the function in question just as well as the design at issue without affecting cost or quality. ${ }^{100}$

On the other hand, another interpretation of the first element of the Inwood/TrafFix test, which is the antithesis of the competitive need test, holds that that a feature is essential "if it plays a material or important role in the product's function," without regard for the availability of alternative designs. ${ }^{101}$ Professor Barrett suggests that this interpretation may have been what the Court intended by its citation to Sears in the TrafFix decision. ${ }^{102}$ This interpretation would potentially render functional all designs, patented or unpatented, except perhaps the purely ornamental.

Such an interpretation would also provide a backdoor for resurrecting the per se bar of Singer and Kellogg. The Tenth Circuit's decision in Vornado provides an example of this interpretation. ${ }^{103}$ There, the court found Vornado's once-patented fan grill design functional despite the fact that Vornado later proved that the fan grill was not the best or most optimal design. The court's reasoning was that if the USPTO found the fan grill design important enough to receive patent protection, then its significance as a useful product feature exceeds its value as a brand identifier. ${ }^{104}$ Similarly, in the Seventh Circuit, Judge Easterbrook found a round sunbathing towel functional and not eligible for trademark protection simply because he deemed a patent claim covering a circular beach towel for sunbathing enough to qualify a round

98. Mark Alan Thurmon, The Rise and Fall of Trademark Law's Functionality Doctrine, 56 FLA. L. REV. 243, 250 (2004).

99. Margreth Barrett, Consolidating the Diffuse Paths To Trade Dress Functionality: Encountering TrafFix on the Way To Sears, 61 WASH. \& LEE L. REV. 79, 88 (2004)

100. See Thurmon, supra note 98 at 268; see also Barrett, supra note 99, at 88; Harold R. Weinberg, Trademark Law, Functional Design Features, and the Trouble with TrafFix, 9 J. INTELL. PROP. L. 1, 18 (2001) (noting that trade dress feature may be nonfunctional if viable alternative exits).

101. See Barrett, supra note 99 , at 88

102. See id. at 88 n.54 and accompanying text.

103. Vornado Air Circulation Sys., Inc. v. Duracraft Corp., 58 F.3d 1498 (10th Cir. 1995).

104. Id. at 1510. 
towel design useful for sunbathers. ${ }^{105}$ These cases illustrate the possibility of a return to a per se bar, where the mere existence of present or past patent disclosure ends the inquiry without an assessment of whether trade dress protection would result in a non-reputation harm that might be offset by the availability of alternative designs.

In addition, the second element of the Inwood test - whether the design feature "affects the cost or quality of the article"-may be interpreted as a "strict construction" of Kellogg, thus removing all but the most arbitrary or incidental designs from trade dress protection. ${ }^{106}$ Such an interpretation would completely disregard trademark law and policy, which aims to preserve competition by ensuring that competitors can compete effectively. An equally important function of a competitive need or marketplace-focused analysis is the maintenance of a fair and ordered marketplace free of the consumer confusion that results from the presence of confusingly similar trademarks and trade dress in the marketplace. Left unqualified, the Inwood/TrafFix test could be interpreted to undermine these important policy purposes.

While the TrafFix Court appears to have turned away from both the policy underlying the functionality doctrine and trademark law's purpose and policy, the Federal Circuit Court of Appeals, successor to the CCPA, reaffirmed its commitment to a competitive need-focused functionality test. The Federal Circuit stated that it did not interpret TrafFix as altering the Morton-Norwich competitive need functionality analysis. The court also acknowledged that the existence of alternative designs is probative of whether a design is functional in the first instance. ${ }^{107}$ The confusion and uncertainty created by the TrafFix/Inwood test screams for a functionality test that takes into consideration the market impact of awarding trade dress protection to a design feature.

Although Professor McKenna writes that TrafFix contemplates "full trade dress protection ... for nonfunctional features," 108 the TrafFix test could very likely eliminate trade dress protection for a number of trade dress eligible designs given the possible interpretations of its key elements. And, there are commentators who continue to call for rules precluding trademark protection for any articles, functional or nonfunctional, that are claimed or disclosed in a patent.

Professor Kevin Mohr argues that extending trade dress protection to product configurations, whether or not claimed or disclosed in a patent, creates the potential problem of depleting available designs for products. ${ }^{109}$ With respect to design depletion, the CCPA in Morton-Norwich mentioned design depletion as a possible concern, but did not provide any discussion as to its import. However, in 1988, the Trademark Trial and Appeal Board (TTAB) directly addressed this concern in In re

105. Jay Franco \& Sons, Inc. v. Franek, 615 F.3d 855, 858 (7th Cir. 2010).

106. See Barrett, supra note 99 , at 89 .

107. Valu Eng'g, Inc. v. Rexnord Corp., 278 F.3d 1268, 1276 (Fed. Cir. 2002).

108. McKenna, (DYS)Functionality, supra note 51, at 843; see also id. at 842-43 \& nn. 83-86.

109. Kevin E. Mohr, At the Interface of Patent and Trademark Law: Should a Product Configuration Disclosed in a Utility Patent Ever Qualify for Trade Dress Protection?, 19 HASTINGS COMM. \& ENT. L.J. 339, 345, 371 (1997). 
Honeywell. ${ }^{110}$ It considered marketplace evidence to determine whether protecting the design as trade dress would adversely affect competitors. Particularly probative was the fact that no entity other than Honeywell had used a round thermostat cover in the marketplace during the twenty years following Honeywell's design patent expiration or the seventeen years since the TTAB's first denial of trade dress protection. The TTAB found the design depletion argument to be of little concern. ${ }^{111}$ Similar types of marketplace queries should be applicable in design depletion cases.

Professor Mark Lemley also objects to awarding trade dress protection to product design. He writes that protecting product designs as trademarks prevents competition in the sale of "those products" and results in price increases. ${ }^{112}$ This latter statement is somewhat misleading. The functionality doctrine prevents trademark protection for any functionally superior design so that competition is not impacted because a competitor is excluded from needed technology. A competitor may compete, but it may not compete by copying another's trade dress. The only competition limited is that which seeks or works to deceive consumers by offering products configured to be identical or confusingly similar to trademark protected designs. For example, the Vita-Mix blender design is protected by a registered trademark. This trademark, however, does not prevent the sale of other blenders that do what the Vita-Mix blender does functionally. What trade dress protection prevents is a competitor's use of an identical or confusingly similar blender design that misleads consumers into believing the knockoff blenders are in fact the more desirable, in my opinion, VitaMix blender. While I take issue with Mohr's and Lemley's positions on the impact of trade dress protection for packaging and product configurations under the doctrine of utilitarian functionality, their objections raise concerns that should be considered under the doctrine of aesthetic functionality.

\section{Aesthetic Functionality at the Patent/Trademark Interface}

Aesthetic functionality arises when protection of a design element "put[s] competitors at a significant non-reputation-related disadvantage." 113 Aesthetic functionality applies in situations where the design does not provide a utilitarian advantage in terms of product performance, yet it provides a competitive advantage intrinsically tied to the design's aesthetic. ${ }^{114}$ The first Restatement of Torts relates an aesthetically functional design to consumer motivation, stating that designs are aesthetically functional when goods associated with the design "are bought largely

110. In re Honeywell, Inc., 8 U.S.P.Q.2d 1600 (T.T.A.B. 1988).

111. Id.

112. Mark Lemley, The Modern Lanham Act and the Death of Common Sense, 108 YALE L.J. 1687, 1696 (1999).

113. Qualitex Co. v. Jacobson Prods. Co., 514 U.S. 159, 165 (1995).

114. See Brunswick Corp. v. British Seagull Ltd., 35 F.3d 1527, 1531, 1533 (Fed. Cir. 1994) (affirming TTAB's determination that the color black for outboard motors was functional because, while it had no utilitarian effect on the mechanical working of the engines, it nevertheless provided other identifiable competitive advantages, such as ease of coordination with a variety of boat colors and reduction in the apparent size of the engines). 
for their aesthetic value," not because of their source identifying function. ${ }^{115}$ As with utilitarian functionality, aesthetic functionality raises the question of the need to copy versus the right to copy. ${ }^{116}$ Professor Mohr argues that protecting product designs as trade dress inhibits marketplace competition because consumer appeal (i.e., the design's aesthetic appeal), not source indication, is the design's primary function. ${ }^{117}$ Mohr's argument raises classic aesthetic functionality concerns. While Mohr's argument seems to focus on the patent law policy of a right to copy unpatented designs, the focus instead should be on the need to copy. Since a design may possess consumer appeal and still qualify as trade dress, a competitor's need to copy is assessed using the traditional aesthetic functionality test to determine the extent of any adverse marketplace impact.

The traditional test for aesthetic functionality includes the same elements considered under the Inwood/TrafFix test for utilitarian functionality, ${ }^{118}$ with heightened focus on whether the design provides a non-reputation related competitive advantage. ${ }^{119}$ The factual inquiry centers on the need to copy versus the right to copy. The balancing of these factors is illustrated in Deere \& Co. v. Farmhand, Inc. ${ }^{120}$ There, Deere had consistently used a particular shade of green to identify its tractors. ${ }^{121}$ When Farmhand introduced front end loaders designed to operate with the Deere tractor, it painted its front end loaders a shade of green identical to Deere's shade of green. ${ }^{122}$ Deere objected on trademark grounds, but the court "conclude[d] that the doctrine of aesthetic functionality ... appl[ied] to the dispute" and "that protection of John Deere green ... would hinder Farmhand in competition." 123 By contrast, in In re Owens-Corning Fiberglass Corp., the Federal Circuit found the color pink for insulation qualified as a trademark because "the color 'pink' has no utilitarian purpose, does not deprive competitors of any reasonable right or competitive need," and is not considered functional on any other grounds. ${ }^{124}$ The aesthetic function involved in Deere \& Co. was the desire to create uniformity

115. RESTATEMENT (FIRST) OF TORTS, supra note 53, § 742, cmt. a. Aesthetic value includes (1) advantages that facilitate coordination with a variety of colors, or those which appear to increase or decrease apparent object size, Brunswick, 35 F.3d at 1533; and (2) designs that facilitate coordination or uniformity, M-5 Steel Mfg., Inc. v. O’Hagin's, Inc., 61 U.S.P.Q.2d 1086 (T.T.A.B. 2001) (finding the shape of a roof vent to be functional because vents "blend in or match the roof tiles with which they are used better than alternative products"). Cf. In re Owens-Corning Fiberglas Corp., 774 F.2d 1116, 1120 21 (Fed. Cir. 1985) (finding color pink not aesthetically functional because no reason to dye insulation pink or any other color).

116. See In re Morton-Norwich Prods., Inc., 671 F.2d 1332, 1339 (Fed. Cir. 1982).

117. See Mohr, supra note 109 at 371.

118. See TrafFix Devices, Inc., v. Marketing Displays, Inc., 532 U.S. 23, 32-34 (2001); see also Morton-Norwich, 671 F.2d at 1341-42.

119. See Qualitex Co. v. Jacobson Prods. Co., 514 U.S. 159, 165 (1995) (stating that when aesthetic design of product is the mark for which protection is sought, the mark is functional if giving the mark holder the right to exclusive use "would put competitors at a significant non-reputation-related disadvantage").

120. Deere \& Co. v. Farmhand, Inc., 560 F. Supp. 85, 98 (S.D. Iowa 1982).

121. Id. at 89 .

122. Id.

123. Id. at 98 .

124. 774 F.2d 1116, 1122 (Fed. Cir. 1985). 
through creating color-coordinated farm equipment, whereas, in Owens-Corning, that same aesthetic function was not a concern because there was no aesthetic need that only the color pink could satisfy. As shown by these cases, aesthetic functionality is typically "limited to product features that serve an aesthetic purpose wholly independent of any source identifying function." 125 That is why the factual analysis in the aesthetic functionality context should turn on whether registration of a design feature hinders competition in some way, not whether the feature has consumer appeal or contributes to the product's commercial success, as some commentators argue. ${ }^{126}$

A design can both possess consumer appeal and be source indicating. For example, the "Wonder Woman" doll design (Fig. 5) may have consumer appeal because it is an aesthetically pleasing design, but that does not diminish its trademark significance. ${ }^{127}$ The Wonder Woman doll design is artistic and has eye-appeal; yet, it also identifies and distinguishes DC Comics' dolls and action figures from those of other doll sellers. There is no competitive need for others to copy this design, except to cause marketplace confusion and disorder. There must be something more than eye-appeal that renders a design functional, as the Second Circuit held in Christian Louboutin S.A. v. Yves Saint Laurent America Holding, Inc. ${ }^{128}$

125. Moldex-Metric, Inc. v. McKeon Prods., Inc., 891 F.3d 878, 885 (9th Cir. 2018) (quoting Millennium Lab’ys, Inc. v. Ameritox, Ltd., 817 F.3d 1123, 1129 (9th Cir. 2016)).

126. See McKenna \& Sprigman, supra note 57, at 527-29.

127. See infra Part IV. See also McKenna \& Sprigman, supra note 57, at 516. McKenna and Sprigman raise the possibility of another type of functionality, phenomenological functionality, which occurs when a product's appeal operates to change consumer perception or preferences. This function is what a good trademark does and should not be the basis for functionality unless the design is the best or one of a few superior design options. Id. For example, the Voss water bottle has appeal because of how it looks. Many consumers, or at least I do, like the design because of its sleek modern lines. It should not be considered aesthetically functional simply because consumers like its aesthetic. If so, few if any designs would qualify as a trademark. And why should others benefit from the creative efforts of one that spends resources to introduce creative products or packaging consumers find aesthetically pleasing, provided those design do not have an anti-competitive impact on the marketplace?

128. 696 F.3d 206, 222 (2d Cir. 2012). But see Pagliero v. Wallace China Co., 198 F.2d 339, 34344 (9th Cir. 1952) (finding floral design on china functional because of its "attractiveness and eyeappeal"). The court noted that where a "particular feature is an important ingredient in the commercial success of the product, the interest in free competition permits its imitation in the absence of a patent or copyright [protection]." Id. at 343. This is where the Ninth Circuit and courts following its reasoning err. 


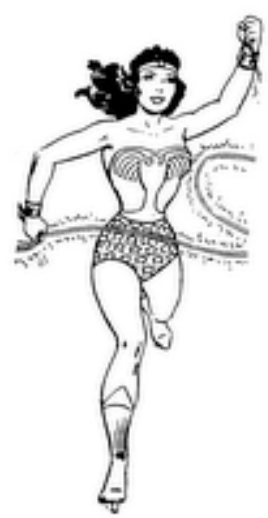

Fig. $5^{129}$

In Louboutin, the Second Circuit found a red, lacquered outsole on a high-fashion woman's shoe, paired with a contrasting upper, to act as a trademark despite the generally aesthetic function of the red sole. ${ }^{130}$ According to the court, trademark significance attached to the red sole despite the district court's determination that the red outsole was "decorative, an object of beauty."131 The Second Circuit correctly reasoned that if the marketplace lacked such protections there would be little incentive to create eye-pleasing designs. Failure to protect aesthetically pleasing but distinctive, nonfunctional trade dress undermines one of trademark law's important policies: protecting consumers from confusion resulting from the presence of confusingly similar designs in the marketplace. ${ }^{132}$

Because it is often difficult to distinguish between aesthetic appeal and branding success, the aesthetic functionality analysis becomes "highly fact-specific" and is seldom applied, which is the reason many courts decline to follow the doctrine. ${ }^{133}$ Yet when addressing the eligibility of a once- or currently patent protected design for trade dress protection, an aesthetic functionality assessment is critical in capturing functionality unrelated to utility, but which gives the product a non-reputation related competitive advantage. The inquiry should focus on "the extent to which the design feature is related to" or associated with "the utilitarian function of the product" at issue, because this is the only way to assess whether function dictates the design or whether the design is completely arbitrary ${ }^{134}$ (like a lacquered red sole on a shoe with a contrasting upper) or an arbitrary flourish (like the design flourish added to the design of a wine decanter in Mogen David).

129. Registration No. 1,236,490 (for toy doll figures).

130. See Louboutin, 696 F.3d at 227.

131. Christian Louboutin S.A. v. Yves Saint Laurent America, Inc., 778 F. Supp. 2d 445, 454 (S.D.N.Y. 2011), rev'd in part, 696 F.3d 206 (2d Cir. 2012).

132. See Qualitex Co. v. Jacobson Prods. Co., 514 U.S. 159, 163-64 (1995); see also Jeanne C. Fromer, The Role of Creativity in Trademark Law, 86 Notre DAME L. ReV. 1885, 1891 (2011).

133. See Louboutin, 696 F.3d at 222 ("[C]ourts must avoid jumping to the conclusion that an aesthetic feature is functional merely because it denotes the product's desirable source.").

134. Keene Corp. v. Paraflex Indus., Inc., 653 F.2d 822, 825 (3d Cir. 1981). 
When the design itself is not significantly related to utility or any other de jure function but is merely arbitrary, it should be entitled to protection as trade dress despite its aesthetics, provided it satisfies the distinctiveness requirements. ${ }^{135}$ In Mogen David, the CCPA made its assessment by examining the type of product involved, the function to be performed, and whether the design was common for the type of product involved. Finding the design an arbitrary flourish for the product at issue and that the design possessed only de facto functionality, the court found the design nonfunctional. Assessing functionality without addressing the design's relatedness to the product and the function performed by that product ignores the fact that trademark rights extend to the mark as used in association with specific goods. ${ }^{136}$ Assessing together product function and design features would also serve to highlight the specific design for which trade dress is claimed, a missing piece of information critical to determining the scope of protection to be awarded the design.

Professors Jeanne Fromer and Mark McKenna raise a legitimate concern regarding the notice and scope of trade dress protection when considering ornamental designs. ${ }^{137}$ To address this issue, the party claiming trade dress protection should be required to specify the particular features of the product design claimed to be trade dress. This explanation should be a required part of a trademark application for registration. For those trade dress marks used under common law, the required statement of particular features must be set forth with particularity in court documents seeking enforcement of trade dress rights. This specification could be analogized to the requirement in a federal trademark registration application that the applicant describe the mark. Without a precise explanation of product-feature association, "courts will be unable to evaluate how unique and unexpected the design elements are in the relevant market" for the particular trade dress. ${ }^{138}$ This statement would also put competitors on notice regarding the scope of protection claimed, giving them the ability to design around it. This required statement solves the notice and scope problems Fromer and McKenna raise. It also assists the courts in determining distinctiveness - a primary requirement for trademarks without which a design cannot function as a trademark.

135. See In re Mogen David Wine Corp., 328 F.2d 925, 931 (C.C.P.A. 1964).

136. See Keene Corp., 653 F.2d at 825. The famous mark exception may extend trademark protection beyond the goods and services identified in the registration. See Grupo Gigante S.A. de C.V. v. Dallo \& Co., 391 F.3d 1088 (9th Cir. 2004).

137. Fromer \& McKenna, supra note 17 at $183-88,190-93$.

138. Yurman Design, Inc. v. PAJ, Inc., 262 F.3d 101, 117 (2d Cir. 2001) (quoting Landscape Forms, Inc. v. Columbia Cascade Co., 113 F.3d 373, 381 (2d Cir. 1997)); see also id. ("[W]ithout a specification of the design features that compose the trade dress, different jurors viewing the same line of products may conceive the trade dress in terms of different elements and features, so that the verdict may be based on inconsistent findings.... [N]o juror can evaluate secondary meaning, overbreadth, or nonfunctionality without knowing precisely what the plaintiff is trying to protect ...."); Landscape Forms, 113 F.3d at 381 ("[A] plaintiff”s inability to explain to a court exactly which aspects of its product design(s) merit protection may indicate that its claim is pitched at an improper level of generality ...."). 


\section{B. Distinctiveness at the Design Patent/Trade Dress Interface}

Once the functionality test has been successfully passed, trademark eligibility rests on whether the design is distinctive, as only distinctive designs are eligible for trademark protection, even where the dress is nonfunctional. ${ }^{139}$ Distinctiveness arises in one of two ways. A design is inherently distinctive if its "intrinsic nature serves to identify a particular source." 140 Acquired distinctiveness occurs when the mark has developed a secondary meaning, that is, when "in the minds of the public, the primary significance of a [mark] is to identify the source of the product rather than the product itself." ${ }^{\prime 14}$ The designs most relevant to the subject of this Article are product packaging and product configuration. Courts have held that product configurations cannot be inherently distinctive, so the party claiming trade dress rights must prove that the configuration has acquired distinctiveness. ${ }^{142}$ Product packaging, however, can be inherently distinctive. The distinction between product configuration and product packaging is that product configuration covers a product's total image and overall appearance, which includes its shape and design and features such as "size, shape, color or color combinations, [and] texture."143 Often product configuration is not readily seen as a source identifier but is associated merely with the product, which why courts require a showing of secondary meaning. By contrast, product packaging covers the containers or wrappers in which a product is sold, but may include such features as size, shape, color, color combinations, texture, or graphics. ${ }^{144}$ Elements of product packaging are often associated with source identifiers and may qualify as inherently distinctive trade dress.

To determine whether a design was inherently distinctive, courts consider

whether it was a "common" basic shape or design, whether it was unique or unusual in a particular field, whether it was a mere refinement of a commonly-adopted and wellknown form of ornamentation for a particular class of goods viewed by the public as a

139. See Wal-Mart Stores, Inc. v. Samara Bros., Inc., 529 U.S. 205, 211 (2000) (“[The Lanham Act] requires that registration be granted to any trademark "by which the goods of the applicant may be distinguished from the goods of others' - subject to various limited exceptions." (quoting 15 U.S.C. $\S 1052)$ ); id. at 209 (first citing Ashley Furniture Indus., Inc. v. Sangiacomo N.A., Ltd., 187 F.3d 363 (4th Cir. 1999) (example of bedroom furniture trade dress); then citing Knitwaves, Inc. v. Lollytogs, Ltd., 71 F.3d 996 (2d Cir. 1995) (example of sweater trade dress); and then citing Stuart Hall Co., Inc. v. Ampad Corp., 51 F.3d 780 (8th Cir. 1995) (example of notebook trade dress)); see also Mogen David, 328 F.2d at 931; In re Morton-Norwich Prods., Inc., 671 F.2d 1332, 1343 (C.C.P.A. 1982).

140. Wal-Mart Stores, 529 U.S. at 210 (alteration in original) (quoting Two Pesos, Inc. v. Taco Cabana, Inc., 505 U.S. 763, 768 (1992)).

141. Id. at 211 (alteration in original) (quoting Inwood Lab'ys, Inc. v. Ives Lab'ys, Inc., 456 U.S. 844, 851 n.11 (1982)); see also 15 U.S.C. § 1052(f) (stating that "nothing [herein] shall prevent the registration of a mark used by the applicant which has become distinctive of the applicant's goods in commerce"-in other words, a mark that has acquired distinctiveness).

142. See Wal-Mart Stores, 529 U.S. at 215-16.

143. Two Pesos, Inc., 505 U.S. at 764 n.1 (quoting John H. Harland Co. v. Clarke Checks, Inc., 711 F.2d 966, 980 (11th Cir. 1983)); see also 1 J. THOMAS MCCARTHY, MCCARTHY ON TRADEMARKS AND UNFAIR COMPETITION $\S 8: 5$ (5th ed.) [hereinafter MCCARTHY ON TRADEMARKS].

144. See Trademark Manual of Examining Procedure, 1202.02 (October 2018). 
dress or ornamentation for the goods, or whether it was capable of creating a commercial impression distinct from the accompanying words. ${ }^{145}$

Acquired distinctiveness assesses whether the public has come to associate the design with a particular source. Evidence of such secondary meaning may include consumer affidavits, consumer surveys, look-for advertising, ${ }^{146}$ treatment by news sources, and an advertising budget and plan to educate consumers that the design is source-identifying trade dress. While inherent distinctiveness or acquired distinctiveness may seem a low bar upon which to rest the eligibility of the subject matter of a design or utility patent for trade dress protection, the test is substantial because it provides evidence of whether consumers have come to associate the product design with a single source. If so, preserving an orderly marketplace by eliminating confusion, deception, fraud, and mistake outweighs the public's right to copy distinctive nonfunctional designs that provide no utilitarian or aesthetic advantage.

The distinctiveness doctrine, together with the functionality doctrine, provide sufficient safeguards to prevent extending trade dress into the domain of patent protectable subject matter in a way that frustrates the objectives of patent law. Distinctiveness ensures that trade dress in designs do what trademarks are supposed to do: "provide an unambiguous identification of source." 147 The functionality doctrine ensures that trade dress protection will not unnecessarily restrain competition by excluding designs that patent law alone should protect. ${ }^{148}$ The following Part proposes a combined distinctiveness-functionality test for determining whether a design that is claimed or disclosed in a patent is also eligible for trade dress protection.

\section{PROPOSED DISTINCTIVENESS-FUNCTIONALITY TEST}

\section{A. Proposed Test}

Existing tests, discussed in Part II, consider whether the design affects the use, function, purpose, cost, or quality of the product, and in some cases whether the design provides a non-reputation related advantage. The proposed test makes identical considerations but takes a more comprehensive view of the proofs required to demonstrate functionality. For example, the CCPA's competitive need test does not expressly consider whether the function to be performed dictates the structure or

145. Seabrook Foods, Inc. v. Bar-Well Foods, Ltd., 568 F.2d 1342, 1344 (C.C.P.A. 1977) (footnotes omitted).

146. See Yankee Candle Co. v. Bridgewater Candle Co., 259 F.3d 25, 44 (1st Cir. 2001) (“"Lookfor advertising' is such that 'encourages consumers to identify the claimed trade dress with the particular producer."').

147. Jay Dratler, Jr., Trade Dress Protection for Product Configurations: Is There a Conflict with Patent Policy?, 24 AIPLA Q.J. 427, 501 (1996).

148. See id. 
shape of the design. ${ }^{149}$ If function dictates design, this is strong evidence pointing toward functionality instead of arbitrary flourish as found in Mogen David and Morton-Norwich. Where function dictates design, the design claimant bears the burden of proving that the design is not one of a superior few.

In a similar manner, the Inwood/TrafFix test also falls short because it is ambiguous and unclear as to the proof required to show functionality. For example, the Inwood/TrafFix test is subject to multiple interpretations. On one hand, the first element of the Inwood/TrafFix test could be equated to the competitive need test, taking into consideration the lack available alternative designs, which would be easily administrable because the evidentiary proofs - alternative designs, or lack thereof-would be clear. On the other hand, the Inwood/TrafFix test could be interpreted as saying that a design or feature is functional if it merely plays a material or important role in the product's overall function despite the existence of alternative designs. This interpretation would render functional virtually all designs. What is needed is a test that provides a comprehensive assessment of functionality that also leaves room for trademark coverage for those designs that are only incidentally related to the function to be performed.

The proposed test outlines seven factors that a court should consider when assessing whether or not a patented design is functional and therefore ineligible for trademark protection. Factors assessed under the proposed test are: (1) whether the proposed design performs a function of any sort, de facto or de jure; ${ }^{150}(2)$ if the function performed is not merely de facto, whether the design is dictated by the function to be performed or is essential to the use or performance of the function such that, if it were missing, the product's function, use, or purpose would be significantly affected; (3) whether the design is one of a few superior designs; (4) whether there are alternative designs, and whether use of an alternative would adversely affect the utility, cost, or quality of the article; (5) whether the design configuration is arbitrary, common, or customary for that type of goods; (6) whether the design possesses an aesthetic quality that enhances the performance of the function or the use of the article, such as the color green in Deere \& Co. v. Farmhand, Inc.; and (7) whether protection of the design would put competitors at a nonreputation related disadvantage. Cumulatively, the factors may warrant a finding of functionality; however, factors (2)-(5) may, individually, support a functionality determination under the doctrine of utilitarian functionality. Factors (2)-(4) are particularly important in weeding out designs that may possess de jure functionality;

149. In Morton-Norwich, the court stated: "We have refrained from using phrases such as 'essentially functional,' 'primarily functional,' and 'dictated primarily by functional considerations' to denote the legal consequence, all of which use the word 'functional' in the lay sense of the term. If, in the legal sense, a particular design is functional, such adverbs as 'essentially' and 'primarily' are without meaning. Either a design is functional (de jure) or it is not." In re Morton-Norwich Prods., Inc., 671 F.2d 1332, 1343 n.4 (C.C.P.A. 1982).

150. If no, the design is purely ornamental and must be assessed for distinctiveness. See id. at 1337 ("[I]f the designation 'functional' is to be utilized to denote the legal consequence, we must speak in terms of de facto functionality and de jure functionality, the former being the use of 'functional' in the lay sense, indicating that although the design of a product, a container, or a feature of either is directed to performance of a function, it may be legally recognized as an indication of source.”). 
factor (4) additionally provides evidence of de facto functionality and whether alternatives designs exist to ensure that competitors are not disadvantaged in the market. Factors (6) and (7) address whether any particular aesthetic feature provides an aesthetic, nonfunctional utilitarian advantage. It is also noteworthy that the Inwood/TrafFix test excludes factor (7); yet, this factor speaks to the very heart of trademark policy — whether trademark protection will adversely affect competition or the consumer's purchasing experience. Where competitive disadvantage is not present but consumer confusion could result from the existence of confusingly similar designs, the default should be in favor of trademark protection, as this supports the trademark policy of facilitating the consumer shopping experience. ${ }^{151}$ Evidence shows that, "[i]f [a] consumer finds a familiar brand in the marketplace, the consumer can identify the source of the product and infer the product's attributes and quality much more quickly than if the consumer laboriously investigates the product to determine its attributes and quality." 152 Under a policy allowing multiple users of distinctive nonfunctional symbols, consumers would face increased search and shopping costs.

Further, in assessing the seven elements of the proposed test, existing case law provides guidance on the type of evidence that courts should consider, as necessary, in making the functionality assessment. Such evidence includes: (a) advertising or utility patents that tout the design's utilitarian or other advantages; (b) preexisting marketplace impact pointing to the nonutilitarian advantages of the design; (c) whether the design is arbitrary, common, or customary for products of the type under analysis; (d) whether the design or overall appearance includes features clearly not dictated by function; (e) evidence assessing the effectiveness of the design in achieving the function in question; and (f) whether the design is unnecessary for performance of the function. To aid the analysis and assessment of the evidence, design owners must identify the specific design features claimed to be trade dress.

The proposed test also provides the clarity that commentators find lacking in the TrafFix test, particularly what is meant by "essential to the use or purpose." ${ }^{153}$ In the proposed test, "essential to use or purpose" as used in factor (2) describes a feature that is material to the product's function or use, without which the product would not function the same way. ${ }^{154}$ As Professor Barrett states, this definition encompasses many more product features than an interpretation that simply looks to the availability of alternative designs. ${ }^{155}$ This definition is also consistent with the CCPA's definition in Morton-Norwich, stating that " 'functionality' is determined in light of 'utility,' which is determined in light of 'superiority of design." 156 In

151. See Qualitex Co. v. Jacobson Prods. Co., 514 U.S. 159, 166 (1995) ("[U]nless there is some special reason that convincingly militates against the use of color alone as a trademark, trademark law would protect Qualitex's use of the green-gold color on its press pads.").

152. See Lee et al., supra note 86 , at 583.

153. See Barrett, supra note 99, at 88.

154. See id.; see also Vornado Air Circulation Sys., Inc. v. Duracraft Corp., 58 F.3d 1498, 1510 (10th Cir. 1995).

155. See Barrett, supra note 100 , at 88.

156. See In re Morton-Norwich Prods., Inc., 671 F.2d 1332, 1340 (C.C.P.A. 1982) (quoting Ives Lab’ys, Inc. v. Darby Drug Co., 601 F.2d 631, 643 (2d Cir. 1979)). 
addition to the materiality of the design to the product's function, the cost of manufacturing the design or a substantial impact on product quality independently speaks to whether the design is functional.

Factor (4) of the proposed test concerning "cost or quality" looks at whether there is a negative impact on either cost or quality such that competitors are left with only inferior functionality or substantial increases in manufacturing costs to produce a competitive item. Put succinctly, the question is: Will protection against copying "hinder the competitor in competition"? ${ }^{157}$ This definition encompasses the CCPA's "superiority of design" and "essential to effective competition" elements, which would include an assessment of alternative available designs or whether competitors are put at a significant non-reputation disadvantage. ${ }^{158}$ The proposed test offers at least three advantages over the Inwood/TrafFix and CCPA/Federal Circuit tests: (1) The functionality of a design is assessed in the context of the particular article supporting the design; (2) the availability of alternative designs is considered in making sure the marketplace would not be harmed by permitting multiple uses of distinctive designs; and (3) aesthetic and utilitarian functionality are assessed together by considering the nature of the product and function to be performed. Together, these elements ensure that the doctrine of functionality fulfills its important public policy purpose of protecting free competition while maintaining a marketplace free of confusingly similar designs that introduce confusion, deception, fraud, and mistake into the purchasing process.

McKenna and Sprigman criticize existing functionality tests for lacking comprehensiveness. ${ }^{159}$ The proposed test is more comprehensive and considers whether the design affects, in any way, the function, use, purpose, cost, or quality of the object; whether the design is, in whole or in part, dictated by the function to be performed; whether it is one of a few superior designs available to the marketplace; and whether exclusive use of the design would put competitors at a non-reputation disadvantage.

Unlike existing functionality tests, the proposed test takes into consideration functionality assessments from related areas of IP law. For example, there are currently separate tests used to determine the functionality of design patent designs, useful articles under copyright law, and trade dress. Functional is functional. Any inquiry into functionality from a trade dress perspective should be broad enough to capture functional designs from both copyright and patent doctrines. This is the only way to ensure that de jure functional designs are not improperly awarded trade dress protection. The Lanham Act $\S 2(\mathrm{e})(5)$, precludes registration of a proposed mark that "comprises any matter that, as a whole, is functional." 160 Practitioners of design patent law may recognize the "function-shape dictation" as an element of the design patent functionality test. Copyright practitioners will likely recognize that this element finds support in copyright law, particularly the distinction between the

157. Id. at 1339 (quoting Truck Equip. Serv. Co. v. Fruehauf Corp., 536 F.2d 1210, 1218 (8th Cir. 1976)).

158. Id. at 1340; see also Qualitex Co. v. Jacobson Prods. Co., 514 U.S. 159, 164-65 (1995).

159. See McKenna \& Sprigman, supra note 57, at 527-29.

160. Lanham Act $\S 2(\mathrm{e})(5), 15$ U.S.C. $\S 1052(\mathrm{e})(5)$ (emphasis added). 
copyrightability of sculptural, pictural, and graphical works embodied on a "useful article" and the "useful article" itself, which the law recognizes as possessing "an intrinsic utilitarian function" making it ineligible for copyright protection. ${ }^{161}$ These additional factors and considerations provide consistency between a functionality for trade dress and that contemplated in the copyright and patent contexts, as functionality in one context should inform functionality in another.

In total, the proposed test provides clearer evidentiary guidance directing the functionality analysis, whereas the Inwood/TrafFix test reintroduced confusion into the functionality doctrine and did little to clear up the inconsistencies among the varying circuits. As the functionality doctrine is the gatekeeper that determines which designs are trade dress eligible, clarity in assessment criteria is vital. The functionality determination is critical to keeping the marketplace free of confusingly similar trade dress or designs that result in a disordered and competitively unfair marketplace. The proposed test provides a basis for uniformity and consistency in making the functionality determination. The next Section illustrates how to implement the test.

\section{B. Application of the Proposed Test}

This Section applies the proposed test to Crocs, Inc.'s ("Crocs") current design trademark in a three-dimensional configuration on the outside of its Classic Crocs Clog shoe. First, this Section considers the types of evidence that would be relevant to making a determination as to the design's functionality. Then, this Section applies elements of the proposed test to Crocs' design trademark to determine whether or not, under the proposed test, the trademark is functional.

\section{Relevant Evidence}

\section{a. Crocs Shoe Design}

The illustrations below show the perspective view drawings of the Crocs shoe as claimed in the trademark registration for the three-dimensional configuration on the shoe (Fig. 6) and the design patent (Fig. 7). The claimed design features are illustrated by the solid lines. The elements shown by broken lines are not claimed features but provide context for what is claimed.

161. See 17 U.S.C. $\S \S 101-102$. 


\section{Trademark Registration}

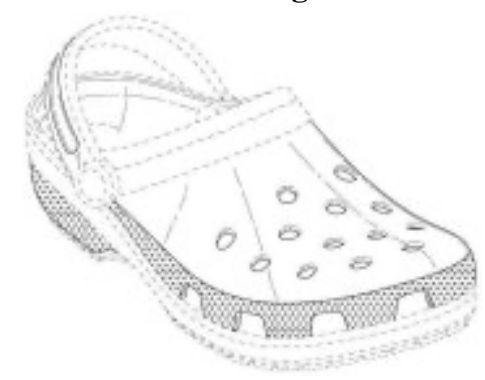

Fig. $6^{162}$
Design Patent

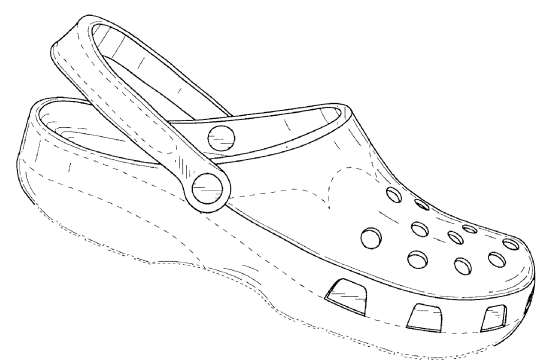

Fig. $7^{163}$

\section{b. Features Claimed as Trade Dress in the Trademark Registration}

Crocs' trademark registration describes the claimed trade dress as follows: "The [trade dress] consists of a three dimensional configuration of the outside design of an upper for a shoe comprising a pattern of 13 round holes on the horizontal portion of the upper of the shoe, a textured strip along the vertical portion of the upper having a pattern of 7 trapezoidal openings, a textured strip on the heel of the shoe and a decorative band along the length of the heel strap."164

\section{c. Features Claimed in the Design Patent}

Crocs' design patent covers the ornamental design for a shoe having an upper, bottom, and strap. The upper includes a U-shaped footwell, a pattern of thirteen round holes on the horizontal portion of the upper of the shoe and a textured strip along the vertical portion of the upper having a pattern of seven trapezoidal openings. The bottom includes a front portion having tread projections and a heel portion with raised bumps. The strap includes a $\mathrm{C}$-shaped design and round strap connectors appearing on each side of the shoe. The design also includes the relative position of these elements to each other. ${ }^{165}$

The difference between the trade dress and design patent claims illustrates important distinctions concerning the scope of trade dress protection. Arguably, Crocs, upon expiration of the design patent, has left open the possibility that the shoe bottom that includes a front portion having tread projections and the $\mathrm{C}$-shaped design and round strap connectors appearing on each side of the shoe become part of the public domain. A court should closely construe the descriptions and hold inconsistencies or omissions against the trademark owner, unless the owner can provide evidence that the elements missing from the trademark description have been used in a source indicating capacity as unregistered trade dress.

162. Registration No. $5,273,875$.

163. U.S. Design Patent No. D517,789.

164. Registration No. 5,273,875 (description of the mark).

165. U.S. Design Patent No. D517,789 figs. 1-7. 


\section{d. Statement of Trade Dress Features Made To Secure Registration}

In order to secure trademark registration, Crocs made a series of statements in its trademark application in response to actions taken by the PTO. According to Crocs in its trademark filings, the element it sought for trademark coverage includes "a three dimensional configuration of the outside design of a shoe consisting of an upper, bottom and strap." The specific design on the upper for which registration is sought includes "a pattern of 13 round holes on the horizontal portion of the upper of the shoe" and a textured strip "along the vertical portion of the upper having a pattern of 7 trapezoidal openings." On the shoe bottom, the design for which registration is sought comprises a front portion "having tread projections and a heel portion with raised bumps." Registration is also sought for a design on the shoe strap consisting of "an oval-shaped ridge and round strap connectors appearing on each side of the shoe." The design also includes "the relative position of these elements to each other."166

Under the proposed test, this modified description would control in future litigation over the alleged functionality of the Crocs design.

\section{Applying the Elements of the Proposed Test}

\section{a. Distinctiveness or Acquired Distinctiveness}

The trademark registration issued under section 2(f) of the Lanham Act, which means that the registrant had to prove the existence of secondary meaning before the registration could issue. As a result, distinctiveness would be assumed under the proposed test.

\section{b. Does the Design Perform a Use or Function?}

Elements considered under this factor are given equal weight. Under the proposed test, determining whether the design feature is functional requires the proponent of trade dress rights to demonstrate the design's nonfunctionality. However, if the trade dress has received a trademark registration, the burden of proving the design functional shifts to the party seeking to cancel the registration or prove noninfringement. In the Crocs shoe example, the presumption is that the design is nonfunctional because of the co-existence of the design patent and the trademark registration. Another factor that points toward nonfunctionality is the seemingly arbitrary placement of the hole-pattern. If the placement of the hole pattern provides no utilitarian advantage with regard to performance, such as airflow through the shoe, this factor would also point toward a nonfunctionality determination. However, if it is determined that the function, purpose, or use of the shoe dictates its design, this

166. U.S. Trademark Application Serial No. 86,913,915, Response to Office Action, Jan. 6, 2017 (description modified in a Response to the Office Action July 6, 2016, requiring an amendment to the description of the mark to define more clearly the scope of mark). 
proof would be dispositive of the inquiry. A feature dictated solely by "functional" (utilitarian) considerations may not be protected as a trademark. ${ }^{167}$

\section{c. Is the Design Essential To the Use or Purpose of the Article?}

Under this factor of the proposed test, evidence of the following, at minimum, is probative: (1) whether the particular hole-pattern provides a functional advantage; (2) whether the configuration of the shoe presents a functional advantage; and (3) whether the hole-pattern around the periphery of the outer upper sole and on the upper sole provide a functional advantage. To answer this question, the following U.S. Patents held by Crocs, Inc. may be relevant for the functionality determination: 10,028,549 (overall shoe configuration); 9,003,677 (sole shape); 8,991,071 (snap in footbed structure); and 6,993,858 (breathable footwear pieces). In particular, U.S. Patent 6,993,858 covers footwear pieces and methods for manufacturing such pieces. The footwear pieces are molded from a lofting material, and in various cases the footwear pieces include one or more ventilators formed in the footwear piece that are surrounded by liquid conductors capable of channeling liquid spilled on the surface of the footwear pieces away from a foot within the footwear pieces. An examination of the teachings of these patents may impact the functionality determination of one or more features for which trade dress protection is sought, as was the case in Kellogg where the formerly design patent protected pillow shape was found to be functional. This element raises a question of fact as to whether the ventilators discussed in the patent correspond to the hole pattern placed on the outside shoe design and whether that pattern enhances the shoe's ability to channel liquid spilled on the surface of the shoe away from a foot within the shoe. If so, it is likely this element would lean toward a finding of functionality.

\section{d. Adverse Effect on the Cost or Quality of the Article}

This factor of the proposed test requires evidence of the cost of manufacturing alternative embodiments, as compared to the cost of manufacturing the design for which trade dress protection is sought; or evidence of whether alternative manufacturing processes would affect the quality of the resultant product. This element raises a question of fact as to whether alternative designs would be costlier to produce or whether the shoe's quality would be adversely affected by alternative designs. If either are true, this element would point toward functionality.

\section{e. Does Advertising Tout the Design's Utilitarian Advantages?}

Under the proposed test, evidence may be presented to assess whether the design owner touts the design as functional or advantageous over other designs. One type of relevant evidence is advertising copy touting the design's functional features. In this case, the ad copy below, used to promote Crocs shoes, would be relevant to the functionality determination, particularly the following underlined factual statements:

167. Cf. In re Deister Concentrator Co., 289 F.2d 496, 502 (C.C.P.A. 1961). 
Original. Versatile. Comfortable.

It's the iconic clog that started a comfort revolution around the world! . . Crocs Classic Clogs offer lightweight Iconic Crocs Comfort ${ }^{\mathrm{TM}} \ldots$. .

Classic Clog Details:

Incredibly light and fun to wear

Water-friendly and buoyant; weighs only ounces

$\underline{\text { Ventilation ports add breathability and help shed water and debris }}^{168}$

Men's Crocs Classic Water Friendly Clogs. Slip into your favorite clog and enjoy a custom fit, water-friendly design, and ventilated forefoot for breathability!

Massaging nubs on the foot bed provide a massage like feel with every step

$\underline{\text { Ventilation ports for breathability and water drainage }}^{169}$

The statements in the advertising copy regarding the "ventilated forefoot for breathability" and "[v]entilation ports for breathability and water drainage" raise factual issues regarding the arbitrariness of the hole pattern. If it is determined that the placement and design of the hole pattern is the best or one of a few superior alternatives in facilitating breathability or water drainage, this factor would also lean toward utilitarian functionality.

\section{f. Is the Design the Best Design or One of a Few Superior Designs?}

This factor of the proposed test considers the specific article to which the design is attached. Here, a shoe. As applied to the Crocs design, the review considers whether the claimed design represents the best hole-design pattern or is one of a few superior designs. According to the text of the Crocs patents and their advertising materials, that which seems to be an arbitrary design may indeed be functional. Under the proposed test, it is quite possible that the Crocs design would not be entitled to trademark protection, particularly if the design and placement of the hole pattern proves to be one of a few superior designs.

g. Does the Proposed Design Present the Design Owner with a Non-Reputation

168. Classic Clog, CROCS.COM, https://perma.cc/T4PM-WG5H (last visited Dec. 6, 2020).

169. Men's Crocs Classic Clogs, SHOECARNIVAL.COM, https://perma.cc/MR83-7VVW (last visited Dec. 6, 2020). 


\section{Related Advantage over Competitors?}

This element requires an examination of whether the design provides an aesthetic advantage that is unassociated with a utilitarian function. On its face, the design does not appear to provide an aesthetic advantage. There is nothing about the design from an aesthetic perspective that competitors would need to access in order to compete in the marketplace. This is not a case where a particular color or shape provides a non-reputation related advantage. ${ }^{170}$ This factor weighs in favor on nonfunctionality.

\section{End Result Under the Proposed Test}

Looking at all of the above factors, the factual evidence regarding the Crocs design presents a close question regarding eligibility of the design for trade dress protection. Statements in the utility patents and advertising copy could tilt the outcome toward functionality, which would bar trade dress protection. Although the hole pattern appears arbitrary, if placement is dictated by function, the design would not qualify for trademark protection. In the end, however, substantial evidence points to the Crocs design's functional advantages. Thus, it is unlikely that the Crocs shoe design properly qualifies for trademark protection under the proposed test.

Some might argue that the factual inquiry is likely to lead to inconsistent results, so imposing labeling restrictions provides a better alternative than extending trade dress protection. But as the Tenth Circuit stated in Vornado, some consumers are likely to ignore product labels, names, and packaging and look only to the designs of product features to tell one brand from another. These consumers are likely to be confused by similar product designs, and to the degree that this confusion is tolerated, the goals of the Lanham Act will be undermined. ${ }^{171}$ Allowing others to copy nonfunctional features disincentivizes providers from investing in creative, eyecatching designs. If a design is nonfunctional, there is no reason for others to copy it, except to create marketplace confusion. ${ }^{172}$

170. See Brunswick Corp. v. British Seagull Ltd., 35 F.3d 1527, 1531, 1533 (Fed. Cir. 1994) (affirming determination that the color black for outboard motors was functional in the aesthetic sense because the color black significantly enhances the performance or use of outboard motors by reducing the apparent size of the engines and facilitating the ease of coordination of the motor with a variety of boat colors). See also Deere \& Co. v. Farmhand, Inc., 560 F. Supp. 85, 98 (S.D. Iowa 1982) (holding that because farmers prefer to match their loaders to their tractors, the doctrine of aesthetic functionality barred John Deere from protecting its unique green color).

171. See Vornado Air Circulation Sys., Inc. v. Duracraft Corp., 58 F.3d 1498, 1509 (10th Cir. 1995).

172. Even though there is no competitive need to copy a nonfunctional device, particularly one formerly or currently protected by patent or copyright protection, commentators raise several problems associated with extending trade dress protection to these designs. A discussion of these concerns is beyond the scope of this Article; however, I highlight a few of the more noteworthy concerns. Jeanne C. Fromer and Mark P. McKenna in their article, Claiming Design, supra note 17, at 196, raise problems of notice and scope of rights, particularly as to the specific rights being claimed. The proposed test discussed in Part III requires the design owner to specify with clarity the scope of the design. Fromer and McKenna also argue that the different methods for claiming the design under the various laws make it harder for courts to give valid rights the correct scope. Determining scope of protection of the same design under different doctrines of protection certainly presents problems. The remedy is perhaps the development of 
Critics of overlapping intellectual property protections and the proposed test raised arguments during various workshopping events that the theory and test favor established companies like Disney and Coca-Cola. Not true. As a practitioner, I pioneered a strategic overlapping IP protection strategy to help small companies protect their innovations. The goal of the strategy was to prevent copycats from trading off a company's goodwill and causing marketplace disorder. I employed this strategy to help a small start-up company secure copyright, design patent, utility patent, and trade dress protection for the design shown in Figs. 8 and 9 for a catshaped pill bottle opener and pill splitter. Using the proposed test, I was able to develop sound legal arguments demonstrating the arbitrariness of the cat-shaped design for the particular goods. The arbitrariness of the design also helped to establish its nonfunctionality, both utilitarian and aesthetic, because it was not one of a superior few. The shape was not dictated by the function to be performed nor would requiring others to use alternative designs for their combination bottle openers and pill splitters adversely affect cost or quality. With respect to aesthetic functionality, the design did not provide a non-reputation related advantage. Consequently, there was simply no competitive need for competitors to copy the design other than to trade on the company's goodwill. The overlapping strategy, particularly trade dress protection, also helped maintain marketplace order because, upon expiration of the design patent, competitors were precluded from selling product designs that caused consumer confusion, mistake, or deception. Even before the design patent expired, copycats popped up in the market. When the company first introduced its product, which it marketed under the trademark the "Purrfect Opener," the product enjoyed enormous market success, which attracted the attention of copycats. However, the overlapping IP protection forced the market to become creative, and various designs for combination bottle openers and pill splitters appeared on the market. Without the ability to assert overlapping design patent, trade dress, and copyright protections, better capitalized copycats would have likely driven this little start-up out of business or infringed its products with impunity. Over twenty years later, this little start-up is still in business. Consistent with patent and trademark law and policy, the overlap strategy worked. The proposed test also worked in providing the legal basis for protection under both the patent, trademark and copyright law.

\footnotetext{
a specialized body that adjudicates intellectual property cases. This body could be a trial court that specializes in IP matters. Trial court decisions would be appealable to the Federal Circuit. Alternatively, the body could be an administrative agency similar to the FTC but designated to hold trials of IP matters with direct appeal to the Federal Circuit or a district court. A specialized body, whatever its form, adjudicating all IP cases would result in uniform law throughout the country. As Professor Andrew Beckerman-Rodau writes in his article, The Problem with Intellectual Property Rights: Subject Matter Expansion, 13 YALE J.L. \& TECH. 35, 89 (2011), the establishment of "a single federal entity or agency with power to oversee all intellectual property, in lieu of the current fragmented approach, might facilitate a more coordinated development of the various bodies of intellectual property law."
} 


\section{Trademark Registration}

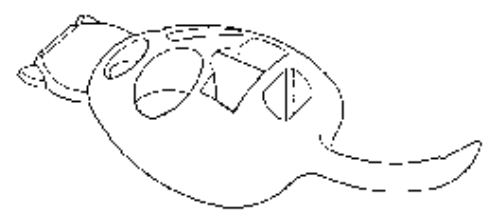

Fig. $8^{173}$

\section{Design Patent}

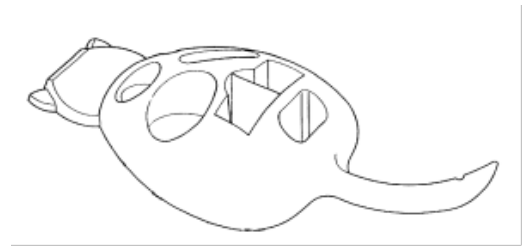

Fig. $9^{174}$

Instead of overlapping and sequential IP protections, some critics argue that "little" companies need to copy larger companies' designs once their patents expire, in order to compete. No, "little" companies need creativity, innovation, and ways to enforce and protect their IP rights to fend off established companies and low-quality imitators. Copying makes small and cash-poor start-ups vulnerable to premature market ouster. Just ask Sean Chen, inventor of the original hoverboard and Jeff Sasaki, founder of Element Case, an iPhone case manufacturer. ${ }^{175}$ Copying, whether it is of patented inventions, trade symbols, or both, injects disorder into the marketplace, making it harder for small companies to compete.

The proposed test addresses the concern that trademark protection for once-patent protected designs would unlawfully extend the patent monopoly for subject matter protectable exclusively under the patent law. It weeds out functional designs, which, by law, are ineligible for trademark protection. Unlike existing tests, the proposed test is more comprehensive in that it considers elements of functionality under both the patent and trademark law to assess whether a design should be excluded from trademark protection on functionality grounds. The proposed test also considers the necessary impact on competition of awarding trademark protection to a onceprotected design. Importantly, this test helps to weed out nonfunctional source indicating designs that, in accordance with trademark law and policy, are eligible for

173. Registration No. 2,873,544 (for non-electric container opener in IC 008 issued to a start-up entrepreneur).

174. U.S. Design Patent No. D492,557 (for the ornamental design of a container opener issued to a start-up entrepreneur).

175. Chris McGreal, The Inventor of the Hoverboard Says He's Made No Money from It, GUARDIAN (Jan. 8, 2016) https://perma.cc/Q5PA-MDPC; Nickels/McHugh/McHugh, Knockoff Products Take a Toll on Small Business, UNDERSTANDING BuS. (May 18, 2015), https://perma.cc/9VPF-422N; see also William J. Keating, The Inventor's Dilemma: The Right To Copy v. Proprietary Rights, 42 ST. JOHN'S L. REV. 38 (1967). There are cases where entrepreneurs have leveraged their overlapping IP rights to keep copyists at bay. See Consent Decree, Rothy's Inc. v. JKM Techs., LLC, No. 3:18-cv-00067 (W.D. Va. Sep. 19, 2019) (parties settle design patent and trade dress lawsuit, with OESH, subsidiary of JKM, acknowledging the validity of Rothy's patent and trade dress and agreeing to redesign its shoe); First Amended Complaint, Benebone LLC v. Pet Qwerks, Inc., No. 8:20-cv-00850 (C.D. Cal. June 11, 2020) (pending design patent and trade dress case where the differences in infringement requirements may be key in preventing unauthorized copying). 
trademark protection, supporting the trademark policy of preserving a fair and orderly marketplace free of confusion, deception, fraud or mistake.

\section{COPYRIGHT/TRADEMARK INTERFACE}

\section{A. DASTAR CORP. V. TWENTIETH CENTURY FOX FILM CORP.}

This Part explores the copyright/trademark interface for distinctive character designs, audiovisual works, and musical compositions. ${ }^{176}$ With regard to threedimensional or useful articles, ${ }^{177}$ the test for trade dress eligibility would follow the functionality test proposed above for designs at the patent/trademark interface. ${ }^{178}$ Since that test applies equally to three-dimensional designs protectable under the Copyright Act, there is no need to repeat discussion of it here. Instead, this Part will focus on the use of character designs and music as trademarks.

Late nineteenth and early twentieth century cases applied a per se bar preventing trademark protection for formerly copyright protected works. ${ }^{179}$ In 2003, the Supreme Court reaffirmed this position in Dastar Corp. v. Twentieth Century Fox Film Corp. ${ }^{180}$ In Dastar, the Court went out of its way to make a "right to copy" ruling similar to that made in Singer and Kellogg. The question before the Court in

176. Fisher v. Star Co., 132 N.E. 133, 139 (1921) ("It appears from the findings of fact that the grotesque figures in respondent's cartoons, as well as the names 'Mutt' and 'Jeff' applied to them have in consequence of the way in which they have been exploited by the respondent and the appearance and assumed characters of the imaginary figures have been maintained, acquired a meaning apart from their primary meaning, which is known as a secondary meaning. The secondary meaning that is applicable to the figures and the names is that respondent originated them and that his genius pervades all that they appear to do or say.”). See also Frederick Warne \& Co. v. Book Sales Inc., 481 F. Supp. 1191, 1195 (S.D.N.Y. 1979) (discussing the images of Peter Rabbit: "[I]t cannot be said that they are so arbitrary, unique, and non-descriptive as to constitute 'technical trademarks,' which are presumed valid as soon as they are affixed to the goods and the goods are sold.").

177. When a three-dimensional article possesses an intrinsic utilitarian function, copyright law considers it a "useful article." Useful articles are eligible for copyright protection "only if, and only to the extent that, such design incorporates pictorial, graphic, or sculptural features that can be identified separately from, and are capable of existing independently of, the utilitarian aspects of the article." 17 U.S.C. $\S 101$.

178. Cf. Star Athletica, L.L.C. v. Varsity Brands, Inc., 137 S. Ct. 1002, 1012 (2017) ("In sum, a feature of the design of a useful article is eligible for copyright if, when identified and imagined apart from the useful article, it would qualify as a pictorial, graphic, or sculptural work either on its own or when fixed in some other tangible medium."). The test for trade dress protection must look beyond conceptual separability and to the underlying utilitarian function performed.

179. See G. \& C. Merriam Co. v. Syndicate Publ'g Co., 237 U.S. 618, 622 (1915) (after the expiration of a copyright, further protection of the name by which the publication was known and sold under the copyright cannot be acquired by registration as a trademark, for the name has become public property, and is not subject to such appropriation); see also Merriam v. Holloway Pub. Co., 43 F. 450 (C.C.E.D. Mo. 1890) (holding that plaintiffs had no right under copyright law to prevent use of the name Webster's Dictionary, but that its claims for unfair competition were valid); Comedy III Prods., Inc. v. New Line Cinema, 200 F.3d 593 (9th Cir. 2000) (finding video clip of The Three Stooges not eligible for trademark protection, as copyright had long expired and Lanham Act cannot be used to extend copyright protection).

180. 539 U.S. 23 (2003). 
Dastar was whether section 43(a) of the Lanham Act prevented the uncredited copying of a work. ${ }^{181}$ Fox's section 43(a) claim asserted that Dastar's release of a video series entitled Campaigns in Europe constituted a false designation of origin because Fox was the source of the intellectual content. Fox had originally produced a television series entitled Crusade in Europe based on a book by the same title written by Dwight D. Eisenhower. Fox failed to renew the copyright for the television series, and it fell into the public domain. Once the copyright registration lapsed, Dastar made minor modifications to the content and released the Crusade in Europe series under the title Campaigns in Europe. Fox argued that Dastar's actions constituted reverse passing off. ${ }^{182}$ It asked the Court to interpret "origin" as used in section 43(a) as referring to the original source of the intellectual content, not the source of the product (the physical videotapes). ${ }^{183}$ However, the Court held that "origin" in section 43(a) referred to the source of the physical videotapes, not the origin of the intellectual content contained thereon. ${ }^{184}$

However, the Court did not conclude its analysis there. In a further part of the opinion that seems off-question, the Court held that trademark rights are not available for subject matter that was once protected by copyright and has since entered the public domain, particularly if the trademark action is essentially a substitute for a copyright infringement action. ${ }^{185}$ Such trademark protection, the Court said, would permit trademark holders to circumvent the Copyright Act and gain perpetual rights to exploit creative works beyond the copyright term. ${ }^{186}$ The Court explained:

The right to copy, and to copy without attribution, once a copyright has expired, like the right to make an article whose patent has expired - including the right to make it in precisely the shape it carried when patented - passes to the public. In general, unless an intellectual property right such as a patent or copyright protects an item, it will be subject to copying. The rights of a patentee or copyright holder are part of a carefully crafted bargain, under which, once the patent or copyright monopoly has expired, the public may use the invention or work at will and without attribution. Thus, in construing the Lanham Act, we have been careful to caution against misuse or overextension of trademark and related protections into areas traditionally occupied by patent or copyright. ${ }^{187}$

181. Lanham Act $\S 43(a), 15$ U.S.C. $\S 1125(a)$. The plain text of 15 U.S.C. $\S 1125(a)(1)$ states: "Any person who, on or in connection with any goods or services, or any container for goods, uses in commerce any word, term, name, symbol, or device, or any combination thereof, or any false designation of origin, false or misleading description of fact, or false or misleading representation of fact, which-(A) is likely to cause confusion, or to cause mistake, or to deceive as to the affiliation, connection, or association of such person with another person, or as to the origin, sponsorship, or approval ... shall be liable in a civil action...."

182. The Court explained that "[p]assing off (or palming off, as it is sometimes called) occurs when a producer misrepresents his own goods or services as someone else's. 'Reverse passing off,' as its name implies, is the opposite: The producer misrepresents someone else's goods or services as his own." Dastar, 539 U.S. at 27 n.1 (2003) (internal citation omitted).

183. Dastar, 539 U.S. at 31.

184. Id. at 37

185. See id. at 33 .

186. Id.

187. Id. at 33-34 (internal quotations, citations and alterations omitted; emphasis added). 
Many read this quote as a per se bar of trademark rights in a once-copyrighted work. ${ }^{188}$ But read in context, this is not what the Court held. Rather, the Court said that trademark protection cannot be used as a substitute to extend or implicate the protections provided by copyright law. ${ }^{189}$ Attribution as to the content owner is what Fox was looking for the Court to impose in Dastar. The Court properly denied that request, as identification of the source of the content contained on the videotapes falls outside the requirements of trademark law. ${ }^{190}$

Although the Dastar Court correctly ruled on the content origin question, its analysis and holding go far beyond the issues before it. ${ }^{191}$ Once the Court defined "origin," that should have ended the review. If "origin" identified product source (the source of the videotapes), as the Court determined it did, and not the content creator, Dastar would not have been liable under section 43(a) for reverse passingoff. Inquiry over; the end. There was no need for the Court to opine on the permissibility of trademark protection for once-copyright protected works. ${ }^{192}$ Notwithstanding the Court's reasoning, the legal community should not construe Dastar's holding as broadly as it has in the past. Professor McKenna articulates that "Dastar should be understood, or at least should be extended, to rule out any claims based on confusion that is attributable to the content of a creative work." 193 I agree, but add the following distinctions: (1) The exclusion from trademark protection should hold in those instances where the challenged item is used in a manner that invokes protections formerly available under copyright; and (2) the exclusion should not apply in those instances where the challenged item is used as a source indicator. However, as explained below, some scholars go further and highlight the tensions raised by Dastar as a basis for maintaining the per se bar at the copyright/trademark interface.

\section{B. Concerns with Copyright/Trademark OverlaP}

Professor Viva Moffat writes that concurrent copyright and trademark protection "disrupts the balance established by Congress and deprives the public of the benefits of the copyright bargain." 194 Moffat seems concerned that a parody of "Mickey

188. See Viva R. Moffat, The Copyright/Patent Boundary, 48 U. RICH. L. REV. 611, 628 n.67 (2014); Tom W. Bell, Misunderestimating Dastar: How the Supreme Court Unwittingly Revolutionized Copyright Preemption, 65 MD. L. REV. 206, 215-17 (2006).

189. Dastar, 539 U.S. at 33.

190. See Mark P. McKenna, Dastar's Next Stand, 19 J. InTELL. Prop. L. 357, 367 (2012) [hereinafter McKenna, Next Stand].

191. See Bell, supra note 188, at 209 ("It looks very much as if the Court said far more than it meant to say precisely because it aimed only to cast a moderate interpretive gloss on $\S 43$ (a) of the Lanham Act.").

192. Laura Heymann posits that the Court seemed motivated by the idea that recognizing "trademark-type rights in areas where copyright may be the dominant form of protection leads to a 'mutant' form of copyright law that impermissibly 'limits the public's federal right to copy and to use expired copyrights' by encroaching upon the public domain." Laura A. Heymann, The Trademark/Copyright Divide, 60 SMU L. REV. 55, 83 \& n.140 (2007).

193. McKenna, Next Stand, supra note 190, at 387.

194. Moffat, supra note 17, at 1516. 
Mouse used in a magazine ... might be deemed fair use under copyright law but might . . . constitute actionable trademark infringement." 195 Professor Moffat raises legitimate concerns; however, there are few instances where a parody under copyright would constitute infringement under trademark law. ${ }^{196}$ Artistic and editorial trademark parodies serve a valuable critical or artistic function, which is entitled to some degree of protection under the First Amendment. ${ }^{197}$ Where the parody involves a commercial use, courts are less likely to find use as a parody; however, courts are more likely to find use as a parody if the use is noncommercial. ${ }^{198}$

Professor Irene Calboli argues that overlapping trademark rights can severely affect society's creativity, limiting the freedom to copy. ${ }^{199}$ She says the right to copy is "crucial to incremental advances in new creative works (as many copyright intensive industries know) and trademark protection in these works can severely impact this freedom."200 I agree there will be an impact on copying, but not to the degree Professor Calboli suggests. Trademark rights will restrict copying and uses that are likely to lead to consumer confusion. And in any likelihood of confusion analysis, the scope of the protected goods and services will be limited to those with which the mark has been used or those that are considered complementary or related. So, any exclusion on copying would be limited to specific market segments and goods. Additionally, if the trademark owner proves secondary meaning, this would indicate that consumers had come to recognize the design as a source indicator, making likelihood of confusion as to source or affiliation more likely; loss of trademark protection would therefore create disorder in the marketplace.

There are better ways to address the concerns raised by Calboli and Moffat than an outright per se bar for trademark protection in copyrighted works. Instead, courts assessing whether a copyrighted work can obtain trademark protection should use the following test proposed in Part V. As shown below, the proposed test contains safeguards that adequately address the concerns raised by Calboli and Moffat.

195. Id. at 1516

196. Bruce P. Keller \& Rebecca Tushnet, Even More Parodic than the Real Thing: Parody Lawsuits Revisited, 94 TRADEMARK REP. 979, 1000 (2004) ("If a joke is recognizable as a joke, consumers are unlikely to be confused, and whether the butt of the joke is society at large, or the trademark owner in particular, ought not to matter at all.").

197. Overview of Trademark Law, BERKMAN KLEIN CTR. FOR INTERNET \& SOC'Y https://perma.cc/2DWK-CNDV (last accessed Dec. 6, 2020) (“[A] risqué parody of an L.L. Bean magazine advertisement was found not to constitute infringement. L.L. Bean, Inc. v. Drake Publishers, Inc., 811 F.2d 26, 28 (1st Cir. 1987). Similarly, the use of a pig-like character named 'Spa'am' in a Muppet movie was found not to violate Hormel's rights in the trademark 'Spam.' Hormel Foods Corp. v. Jim Henson Prods., 73 F.3d 497 (2d Cir. 1996). On the other hand, 'Gucchie Goo' diaper bags were found not to be protected under the parody defense. Gucci Shops, Inc. v. R.H. Macy \& Co., 446 F. Supp. 838 (S.D.N.Y. 1977). Similarly, posters bearing the logo 'Enjoy Cocaine' were found to violate the rights of Coca-Cola in the slogan 'Enjoy Coca-Cola.' Coca-Cola Co. v. Gemini Rising, Inc., 346 F. Supp. 1183 (E.D.N.Y. 1972).”).

198. See id.

199. See Calboli, supra note 17, at 30.

200. Id. 


\section{PROPOSED TEST AND ITS APPLICATION}

The distinctions drawn above regarding Dastar's scope lead to the following three-part test for assessing trademark protection of copyright protected designs. Courts should assess: (1) Is the design used in a manner that invokes protections formerly available under copyright? (2) Is the design aesthetically functional? and (3) Is the design inherently distinctive, or has it acquired distinctiveness? ${ }^{201}$ The Dastar test merely assesses whether the subject matter at issue has been protected by copyright, but that test is overbroad and leaves unprotected distinctive articles that serve a source indicating function. While the proposed test does not resolve all issues concerning overlapping or sequential copyright/trademark protections, courts must be mindful to set and enforce norms that determine marketplace practices affecting the fairness and orderliness of the marketplace. A per se rule of preclusion is harmful to the maintenance of a fair and ordered marketplace, as the following examples show.

\section{A. GEORge GERShWIN's “RHAPSODY IN BLUE” AS A TradeMARK}

This example is taken from Laura Heymann's article, The Trademark/Copyright Divide. $^{202}$ It addresses an actual use of a once-copyright protected work as a trademark:

United Airlines ... currently uses ... Rhapsody in Blue as the theme music for its television commercials. If United continues to do so after the song enters the public domain, it would seem illogical that a new entrant into the airline services market could create confusion in the marketplace as to the source of its services by using the song as its advertising theme music and yet successfully defend a suit by United on the ground that the song was now in the public domain and thus free from any legal restrictions on its use. ${ }^{203}$

With aesthetic functionality not being an issue in this case, applying the three-part test breaks down as follows: (1) The song has been appropriated from the public domain for a limited, non-copyright related use as a trademark; (2) United's enforcement of its rights is limited to remedies provided under the Lanham Act, meaning others have the right to copy and use the music for all purposes except as a trademark for airline services; and (3) United would be required to prove secondary meaning (acquired distinctiveness). Proof of secondary meaning is key because it would indicate that consumers view the song as a trademark associated with a particular source. If United can show that consumers associate the song with its services, United must be able to assert its trademark rights to prevent a competitor

201. The proposed approach should be applied in those instances where the copyright on the character at issue has entered the public domain. I acknowledge and agree that "characters that are 'especially distinctive' or the 'story being told' receive protection apart from the copyrighted work." Rice v. Fox Broad. Co., 330 F.3d 1170, 1175-76 (9th Cir. 2003) (citing Olson v. Nat'l Broad. Co., 855 F.2d 1146, 1452 (9th Cir. 1988)).

202. See Heymann, supra note 192, at 86-87.

203. Id. 
from appropriating the same song as a trademark to identify its airline services, in order to maintain an ordered marketplace.

\section{B. Comedy III Productions, Inc. V. NeW Line Cinema: The Three STOOGES AS A TRADEMARK}

In the 2000 case, Comedy III Productions, Inc. v. New Line Cinema, the Ninth Circuit held that once-copyright protected subject matter cannot be protected under trademark law if the trademark protection is merely an extension of copyright protections. ${ }^{204}$ In that case, Comedy III complained that New Line's use of a video clip of The Three Stooges in its film was trademark infringement. Comedy III claimed the clip to be a trademark identifying the comedy of The Three Stooges. Copyright protection for the video footage had expired long before New Line's use. The court found that Comedy III was attempting to use the Lanham Act to circumvent copyright law. Acknowledging the per se bar of trademark protection for the video clip, the court held that "material covered by copyright law [that] has passed into the public domain ... cannot then be protected by the Lanham Act without rendering the Copyright Act a nullity." However, the court intimated that "[h]ad New Line used the likeness of The Three Stooges on t-shirts which it was selling, Comedy III might have an arguable claim for trademark violation." 205

The court distinguished a copyright-like use from a trademark use. A use that implicates copyright protections is not a qualifying use, but a use of the design as a source indicator qualifies it as protectable under trademark law. Professor Irene Calboli has asked: "[I]f the Three Stooges characters are in the public domain, why should their 'free' use be limited to showing the characters in another movie and not on t-shirts (or a mug or any other tangible medium of expression)?"206 The answer is: Because the public also has a right to be free from confusion in the marketplace as to sponsorship or affiliation.

The New Line Cinema result is likely what the Dastar Court intended. Any other meaning makes no sense from a trademark, market ordering perspective. New Line Cinema's reasoning allows for dual protection with limitations prohibiting the claiming of copyright-like benefits.

\section{Steamboat Willie and Betty Boop as Trademarks}

The issues become much harder to sort out when the design involved has obtained de facto secondary meaning, as with Steamboat Willie ("SWB") (Fig. 10) and Betty Boop (Fig. 11), because of their long period of exclusive use under copyright. The proposed test examines the use in question to determine whether the design is being used in its ordinary copyright sense (for example, as a character in an audiovisual work, a stuffed animal, or an action figure) or if it is associated with the sale of goods or services in a primary or secondary source indicating capacity.

204. 200 F.3d 593, 595 (9th Cir. 2000).

205. Id. at 596 .

206. Calboli, supra note 17, at 32. 


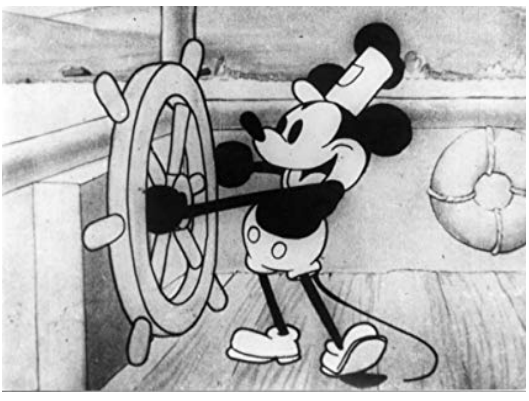

Fig. 10

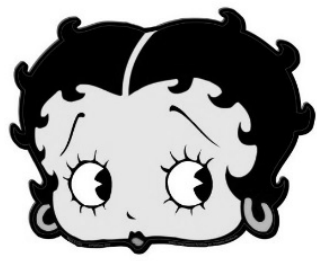

Fig. 11

With respect to characters, characters qua characters would be eligible for trademark protection in limited circumstances upon expiration of their copyright protection. $^{207}$ In the case of SBW, the public would be able to depict the character in film clips as a character in the way The Three Stooges were depicted in New Line Cinema. However, use of SBW as a trademark at the beginning of a film to indicate origin would not be a permissible use of the SBW character.

The same is true for the Betty Boop character. In Fleischer Studios v. A.V.E.LA. (Fleischer Studios I), ${ }^{208}$ Flesicher complained that defendants' use of the comic strip character Betty Boop (Fig. 11) on T-shirts would confuse the public as to the source of the shirts. ${ }^{209}$ Defendants argued that its Betty Boop character was based on vintage posters featuring Betty Boop's image that it had restored, giving it copyright interests in the restored image. ${ }^{210}$ While the Ninth Circuit issued a superseding opinion on this issue, under the proposed test in Fleischer Studios I, the inquiry becomes whether the image is used as expressive content or as a source indicator.

207. This exclusion would apply only to those versions of the character design that enter the public domain upon expiration of the copyright. For example, SBW enters the public domain on January 1,2024, but there are modern versions of Mickey Mouse that remain copyright protected.

208. Fleischer Studios v. A.V.E.L.A., 636 F.3d 1115 (9th Cir. 2011) (Fleischer Studios I). But see Fleischer Studios, Inc. v. A.V.E.L.A., Inc., 654 F.3d 958, 961, 968 (9th Cir. 2011) (Fleischer Studios II) (withdrawing and superseding the prior opinion and raising questions of fact as to whether Betty Boop image has obtained secondary meaning).

209. Fleischer Studios claims rights in the Betty Boop image under the following chain of title: "Original Fleischer transferred its rights to Paramount Pictures, Inc. (Paramount) in 1941; Paramount transferred those rights to UM \& M TV Corp. (UM \& M) in 1955; in 1958, UM \& M transferred these rights to National Telefilm Associates, Inc. (NTA), which became Republic Pictures in 1986; and finally, Republic Pictures transferred the exclusive copyright to Fleischer in 1997." Fleischer Studios I, 636 F.3d at 1118. The district court found that Fleischer failed to prove the chain of title and denied Fleischer Studios' claim of copyright ownership. Id. The Ninth Circuit affirmed. Id. at 1122.

210. Id. at 1118 . 
The use of images, logos, and signs on T-shirts in the manner the defendants in Fleischer Studios I intended is a trademark use. ${ }^{211}$ While it is arguable that such uses are purely ornamental and not source indicating, the consuming public recognizes such use as being authorized or sponsored by the trademark owner. ${ }^{212}$ When one uses another's trademark in a primary or secondary source indicting capacity, this raises "[o]ne of the most valuable and important protections" the Lanham Act affords a trademark owner - "the right to control the quality of the goods manufactured and sold under the ... trademark [owner's mark]."213 Permitting the defendant in Fleischer Studios I to use Betty Boop's image on T-shirts not only leads to consumer confusion, ${ }^{214}$ it also robs the trademark owner of the right to control the quality of goods sold under its mark. ${ }^{215}$ This kind of unfettered use may even expose a trademark holder to a products liability claim under the Apparent Manufacturer Doctrine. $^{216}$

211. See Arthur Schwartz, The Foreign Trademark Owner Living with American Products Liability Law, 12 N.C. J. INT'L L. \& COM. REGUL. 375, 375 (1987) (common for a trademark owner to license the use of his or her trademark for placement on goods manufactured by a third party); Alfred M. Marks, Trademark Licensing_Towards a More Flexible Standard, 78 TRADEMARK REP. 641, 648 (1988) (trademark owners commonly license use of the mark on goods that are unrelated to the trademark owner's primary business, e.g., Coca-Cola licensing its mark for use on clothing).

212. 15 U.S.C. $\S 1125(a)(1)(A)$. Confusion resulting from this type of use is referred to as "sponsorship confusion." See also 4 MCCARTHY ON TRADEMARKS, supra note 143, § 24:7 (5th ed.) (citing Triangle Publ'ns, Inc. v. Rohrlich, 167 F.2d 969 (2d Cir. 1948)) (teenage girls might assume magazine's endorsement of girdles); Triangle Publ'ns, Inc. v. Standard Plastic Prods., Inc., 241 F. Supp. 613 (E.D. Pa. 1965) (teenage girls might assume magazine's endorsement of luggage); Shawnee Milling Co. v. Sidney Wanzer \& Sons, Inc., 390 F.2d 1002, 1003 (C.C.P.A. 1968) ("If [ordinary shoppers] were to see SILVER SPOON flour on one shelf and SILVER SPOON ice cream around the corner in a freezer, it seems more than likely that many of them would ascribe a common sponsorship.").

213. El Greco Leather Prods. Co v. Shoe World, Inc., 806 F.2d 392, 395 (2d Cir. 1986) (emphasis added).

214. Cf. Mark A. Lemley \& Mark McKenna, Irrelevant Confusion, 62 StAN. L. ReV. 413, 415 (2010) (sponsorship or affiliation confusion is likely to cause consumers to believe that the trademark owner stands behind or guarantees the quality of the defendant's goods or services). Lemley and McKenna argue that perhaps this type of confusion should be addressed under the false advertising laws and not as trademark infringement. $I d$.

215. Critics argue that use leading to sponsorship confusion, such as a sports logo on a shirt or the picture of an expressive character on a T-shirt, do not serve the traditional trademark function, as consumers do not perceive the mark holder as standing behind the quality of the merchandise. While this may be true, consumers likely understand this type of use to be authorized by the trademark holder, leading to sponsorship confusion. See Mark A. Kahn, May the Best Merchant Win: The Law of Non-Trademark Uses of Sports Logos, 14 MARQ. SPORTS L. REV. 283, 303-4 (2004).

216. See Restatement (ThiRd) OF TORTs: Products Liability $\S 14 \mathrm{cmt} . \mathrm{d}$ (AM. L. InSt. 1998) (stating that the doctrine does not apply to impose liability on a trademark owner who grants a manufacturer a license to use the trademark or logo on the product, so long as the trademark owner does not substantially participate in the product's design, manufacture, or distribution); see also RESTATEMENT (SECOND) OF TORTS $\S 400$ (AM. L. INST. 1965) ("One who puts out as his own product a chattel manufactured by another is subject to the same liability as though he were its manufacturer."). While these two provisions conflict, "courts ... have applied the apparent manufacturer doctrine to non-selling, non-distributing trademark licensors." David J. Franklyn, The Apparent Manufacturer Doctrine, Trademark Licensors and the Third Restatement of Torts, 49 CASE W. RSRV. L. REV. 671, 675 (1999). This situation could easily arise, as consumers often associate the goods sold under a particular trademark with a certain level of quality and safety. Rather than conduct an actual investigation into a product's 
Permitting this type of use creates disorder in the marketplace as to affiliation or sponsorship and is the kind of use barred under the proposed test. So, I must disagree with Professor McKenna that the court correctly decided the Fleischer Studios case in Fleischer Studios I. I must also disagree with Professor McKenna that unfair competition or false advertising should decide cases where the trademark is used on products in a secondary source indicating way instead of as a primary source indicator. ${ }^{217}$ Unauthorized uses of the type defendants made in Fleischer Studios I are likely to mislead consumers as to affiliation and sponsorship. If defendants produce poor quality items or engage in conduct that harms the public, this harm will likely be imputed to plaintiffs. Thus, a plaintiff should have the right to control the use of its mark and to protect its good name and the goodwill associated with its products.

Preventing confusion of source, affiliation, or sponsorship is precisely why trademark's marketplace ordering function is important and why the public's right to copy must yield to trademark law. The natural law origin of the right to copy supports a suspension of the right in support of higher order public policy considerations. One higher order policy consideration is maintaining order in the marketplace by preventing consumer confusion, mistake, and deception due to multiparty use of identical or confusingly similar designs and things in marketing their products. At its genesis, the right to copy applied to all things introduced into the Unrestricted Common. Thus, to maintain order as society sought to advance the state of the common through creation and innovation, an exception to copying was necessary, as explained in Part II.2.

As previously stated, the right to copy is not absolute, as the positive law warrants exceptions to effectuate its purpose and policies. When faced with two seemly contradictory laws or policies, there must be a careful balancing to determine which, if any, must give way to the other, as discussed in the following Part.

quality and safety, consumers tend to rely upon the trademark holder's reputation. See id. If a consumer reasonably believes that the trademark owner placed the goods into commerce, the consumer will demand the trademark owner answer for the quality and safety issues. Ultimately, the trademark owner will be able to remove itself from the action by showing that it had not authorized use of the trademark or manufactured the goods in question. However, making this showing a requirement harms the trademark owner in two ways: (1) it has to uses resources to extricate itself from litigation; and (2) it will have to spend resources to ameliorate its reputation with those consumers who justifiably rely on the trademark as an indication that the trademark owner is the source of unsafe or low-quality goods. As has been said throughout this Article, preventing marketplace confusion and disorder of this type outweighs a competitor's need to copy and supports overlapping and sequential trademark rights for copyright and patent protected designs.

217. See Lemley \& McKenna, supra note 214, at 454 ("We suggest that trademark law can best deal with sponsorship or affiliation claims by taking a page from history and returning this subset of cases to its roots in false advertising law."). 


\section{STATUTORY BASES FOR OVERLAPPING AND SEQUENTIAL IP RIGHTS}

\section{A. Balancing Conflicting Statutes}

Permitting overlapping or sequential IP rights arguably presents a conflict between three statutory provisions. Some courts and scholars argue that patent and copyright law preempt trademark law, so trademark rights automatically yield to copyright and patent law in a dispute of rights conflict. ${ }^{218}$ Not true. The Court in J.E.M. Ag Supply, Inc. v. Pioneer Hi-Bred International, Inc. stated that, when assessing conflicting statutes, courts must balance and weigh the purposes and scope of each, particularly where overlapping protections are concerned. ${ }^{219}$

In J.E.M. Ag Supply, the issue before the Court was whether the same plant variety could be protected under both the utility patent statues and the Plant Variety Protection Act (PVPA). ${ }^{220}$ Pioneer argued that "when statues overlap and purport to protect the same commercially valuable attribute of a thing, such 'dual protection' cannot exist." "221 The Court rejected Pioneer's argument, stating that "this Court has not hesitated to give effect to two statutes that overlap, so long as each reaches some distinct cases."222 The Court went on to explain that although utility patents and PVPA certificates "contain some similar protections, the overlap is only partial." 223 The Court highlighted two instances in which it had allowed dual protection in IP cases where different attributes of an article were protectable under the different IP schemes at issue. ${ }^{224}$ As long as each statute "reaches some distinct cases" warranting protections that the other does not reach, "overlap do[es] not pose an either-or proposition." 225

\section{B. Reconciling FEderal IP Statutes}

When two statutes are in conflict, and if Congress has not identified which statute should be applied in the event of a conflict, courts must make that determination. ${ }^{226}$

\footnotetext{
218. See Singer Mfg. Co. v. June Mfg. Co., 163 U.S. 169 (1896); Kellogg Co. v. Nat'l Biscuit Co., 305 U.S. 111 (1938).

219. 534 U.S. 124, 144 (2001).

220. 84 Stat. 1542 , amended by 7 U.S.C. $\$ 2321$ et seq.

221. Brief for Petitioners at 44-45, J.E.M. Ag Supply, Inc. v. Pioneer Hi-Bred Int'l, Inc., 534 U.S. 124 (2001) (No. 99-1996).

222. J.E.M. Ag Supply, 534 U.S. at 144 (citing Conn. Nat'l Bank v. Germain, 503 U.S. 249, 253 (1992)) ("'S]tatutes that overlap 'do not pose an either-or proposition' where each confers jurisdiction over cases that the other does not reach.").

223. Id. at 144 .

224. Kewanee Oil Co. v. Bicron Corp., 416 U.S. 470, 484 (1974) (holding that there is no conflict between trade secret and utility patent protection); Mazer v. Stein, 347 U.S. 201, 217 (1954) (stating in dicta that the patentability of an object does not preclude the copyright of that object as a work of art).

225. J.E.M. Ag Supply, 534 U.S. at 144 (citing Mazer, 347 U.S. at 217 ("[T] object does not preclude the copyright of that object as a work of art.")); see also Kewanee Oil Co., 416 U.S. at 484 .

226. J.E.M. Ag Supply, 534 U.S. at 141-42.
} 
They must interpret statutes and apply each in a way that preserves their respective purposes and fosters harmony between them. ${ }^{227}$ Doing this requires an assessment of the purpose and policy underlying each statute.

Starting with patent law, patent policy begins with the IP Clause mandate to "promote the Progress of Science and useful Arts." 228 In exchange for the grant of limited rights, the patentee must fully disclose the invention in a written application. Disclosure insures that upon expiration of the patent term the public possesses the knowledge necessary to practice the invention, without restriction. ${ }^{229}$ Disclosure and public possession help promote the policies underlying patent law, which are: (1) to foster and reward invention or to promote the decorative arts; (2) to promote disclosure of inventions to stimulate further innovation and to permit the public to practice the invention once the patent expires; and (3) to assure that ideas in the public domain remain there for the free use of the public. ${ }^{230}$

In the copyright context, the Supreme Court has found key similarities between the public policies of copyright and patent. Specifically, copyright law policy and purpose seek to advance the public welfare by: (1) motivating the creative activity of authors ${ }^{231}$ (2) allowing the public access to the products of their genius after the limited period of exclusive control has expired; ${ }^{232}$ and (3) inducing release to the public of the products of an author's creative genius. ${ }^{233}$

227. Id. at 143-44 (stating that where there are apparently conflicting statutes that are "capable of co-existence, it is the duty of the courts, absent a clearly expressed congressional intention to the contrary, to regard each as effective"). See also New York v. Ferber, 458 U.S. 747, 769 \& n.24 (1982) (compiling cases); Vornado Air Circulation Sys., Inc. v. Duracraft Corp., 58 F.3d 1498, 1507 (10th Cir. 1995) (citing Digital Equip. Corp. v. Desktop Direct, Inc. 511 U.S. 863, 879-80 (1994)); Brotherhood of R.R. Trainmen v. Chicago River \& Ind. R.R., 353 U.S. 30, 40-42 (1957).

228. U.S. CONST., art. I, $\S 8$, cl. 8 . This section presents a joint discussion of design and utility patent policy and purpose, as a number of courts suggest that design patent policy follows that of utility patent policy. See Forestek Plating \& Mfg. Co. v. Knapp-Monarch Co., 106 F.2d 554 (6th Cir. 1939); Robert W. Brown \& Co. v. De Bell, 243 F.2d 200 (9th Cir. 1957); Hueter v. Compco Corp., 179 F.2d 416, 417 (7th Cir. 1950) (stating the purpose of design patent law is to promote decorative arts and stimulate exercise of inventive faculty in improving appearance of articles of manufacture); Hadco Prods., Inc. v. Walter Kidde \& Co., 462 F.2d 1265, 1273-74 (3rd Cir. 1972) (stating the purpose of design patent statute is to reward and thereby encourage creative artistic activity rather than mere changes of detail which may produce novelty but do not reflect invention, and while distinctions in detail may sustain design as novel, they lose significance in establishing non-obviousness.); Avia Grp. Int'l, Inc. v. L.A. Gear Cal., Inc., 853 F.2d 1557, 1563 (Fed. Cir. 1988) ("When function dictates a design, protection would not promote the decorative arts, a purpose of the design patent statute.").

229. Kewanee, 416 U.S. at 480-81 (quoting United States v. Dubilier Condenser Corp., 289 U.S. 178, 187 (1933)). The Supreme Court has expressed what could be considered one limitation on this right, in Compco Corp. v. Day-Brite Lighting, Inc., 376 U.S. 234, 238 (1964) ("[I]f [a] design is not entitled to a design patent or other federal statutory protection, then it can be copied at will.").

230. Aronson v. Quick Point Pencil Co., 440 U.S. 257, 262 (1979) (citing Kewanee, 416 U.S. at 480-81).

231. Mazer v. Stein, 347 U.S. 201, 219 (1953); see also United States v. Loew's, Inc., 371 U.S. 38, 44-51 (1962); United States v. Paramount Pictures, 334 U.S. 131, 154-59 (1948).

232. Mazer, 347 U.S. at 215.

233. Paramount Pictures, 334 U.S. at 158. 
Finally, the Court has announced at least three purposes of the trademark law: (1) to reduce the customer's costs of shopping and making purchasing decisions, ${ }^{234}$ (2) to assure the producer that it (and not an imitating competitor) reaps the financial, reputation-related rewards associated with the sale of products, ${ }^{235}$ and (3) to encourage the production of quality products. ${ }^{236}$

Each statute includes the common goals of promoting the public good through either innovation/creation or promoting commerce by maintaining a fair and ordered marketplace. However, each statute provides protection for distinct designs, as required by J.E.M. Ag Supply. Table 1, below, presents a visual illustration of J.E.M. Ag Supply's teachings as applied to IP overlap among conflicting copyright, patent, and trademark statutes. Each statute protects distinct attributes of an article. Each is directed to distinct subject matter with different rules and requirements for receiving protection, and each act requires different proofs to enforce its rights.

Table 1

\begin{tabular}{|c|c|c|c|c|}
\hline IP Rights & Utility Patent & Trademark & Design Patent & Copyright \\
\hline $\begin{array}{l}\text { What It } \\
\text { Protects }\end{array}$ & $\begin{array}{l}\text { Functionality- } \\
\text { practical utility }\end{array}$ & $\begin{array}{l}\text { Words, } \\
\text { symbols, } \\
\text { devices, and } \\
\text { trade dress that } \\
\text { act as a source } \\
\text { identifier }\end{array}$ & $\begin{array}{l}\text { Ornamental } \\
\text { features-how } \\
\text { something } \\
\text { looks }\end{array}$ & $\begin{array}{l}\text { Works of } \\
\text { authorship }\end{array}$ \\
\hline $\begin{array}{l}\text { Elements } \\
\text { Required for } \\
\text { Protection }\end{array}$ & $\begin{array}{l}\text { Invention must } \\
\text { be new, useful, } \\
\text { and non- } \\
\text { obvious; and } \\
\text { directed to a } \\
\text { machine, } \\
\text { process, article } \\
\text { of manufacture, } \\
\text { or composition } \\
\text { of matter }\end{array}$ & $\begin{array}{l}\text { The proposed } \\
\text { mark or dress } \\
\text { must be } \\
\text { distinctive or } \\
\text { capable of } \\
\text { acquiring } \\
\text { distinctiveness }\end{array}$ & $\begin{array}{l}\text { The design } \\
\text { must be new, } \\
\text { original, and } \\
\text { an ornamental } \\
\text { feature for an } \\
\text { article of } \\
\text { manufacture }\end{array}$ & $\begin{array}{l}\text { Originality, } \\
\text { fixed in a } \\
\text { tangible } \\
\text { medium of } \\
\text { expression }\end{array}$ \\
\hline $\begin{array}{l}\text { Infringement } \\
\text { Test }\end{array}$ & $\begin{array}{l}\text { Each element or } \\
\text { its equivalence } \\
\text { must be present } \\
\text { in the accused } \\
\text { device }\end{array}$ & $\begin{array}{l}\text { Likelihood of } \\
\text { confusion- } \\
\text { multifactor test } \\
\text { that considers } \\
\text { the similarity } \\
\text { or dissimilarity } \\
\text { of the marks, } \\
\text { the goods/ } \\
\text { services, trade } \\
\text { channels, etc. }\end{array}$ & $\begin{array}{l}\text { Ordinary } \\
\text { observer- } \\
\text { substantial } \\
\text { similarity in } \\
\text { the eyes of an } \\
\text { observer } \\
\text { viewing the } \\
\text { design in } \\
\text { context of the } \\
\text { prior art }\end{array}$ & $\begin{array}{l}\text { Access, proof } \\
\text { of copying, } \\
\text { substantial } \\
\text { similarity }\end{array}$ \\
\hline
\end{tabular}

234. Qualitex Co. v. Jacobson Prods. Co., 514 U.S. 159, 163-64 (1995) (quoting 1 J. Thomas MCCARTHY, MCCARTHY ON TRADEMARKS AND UNFAIR COMPETITION $§ 2.01$ [2] (3d ed. 1994)).

235. Id. at 164 .

236. Id. It "simultaneously discourages those who hope to sell inferior products by capitalizing on a consumer's inability quickly to evaluate the quality of an item offered for sale." Id. 
In J.E.M. Ag Supply, the Court found conflicting IP statutes capable of coexisting and capable of extending IP protections to the same article, because each statute (1) provided different protections, (2) imposed different requirements for receiving protection, (3) provided different scopes of exclusion, and (4) protected different attributes in the subject article. Like the statutes in J.E.M. Ag Supply, the statutes here are capable of coexisting because of their different purposes and policies and different schemes of protection. ${ }^{237}$ In view of the foregoing, courts should regard the IP laws at the patent/trademark and copyright/trademark interfaces effective in their respective parings under the teachings of J.E.M. Ag Supply. Each pair imposes different requirements to obtain and enforce rights and each provides different protections.

Finally, the notion of overlapping rights or penalties exist in other areas of the law, so why should IP be any different? ${ }^{238}$ The answer is: IP should not be treated differently. The Court's holding in J.E.M. Ag Supply provides a clear and compelling argument for replacing the per se bar with a statutory analysis reconciling the purpose and policy supporting the conflicting provisions. ${ }^{239}$

\section{CONCLUSION}

This Article began by asking whether U.S. intellectual property law should permit overlapping and sequential trademark protection for designs that are or once were protected by copyright or patent. Based on the foregoing, the general rule should be that nonfunctional designs, whether the subject of an existing or expired copyright or patent, should be eligible for trademark or trade dress protection. Keeping in mind the functions of trademark law, a per se bar of trademark protection is too harsh a remedy. Balancing the "right to copy" against the "need to copy" strikes an appropriate balance between fair and unfair competition. Where there is no need to copy a design to be competitive, the right to copy should yield to preservation of a fair or orderly marketplace, which protects a trademark owner's trade symbols.

237. J.E.M. Ag Supply, Inc. v. Pioneer Hi-Bred Int'l, Inc., 534 U.S. 124, 143-44 (2001) (citing Morton v. Mancari, 417 U.S. 535, 551 (1974)).

238. Overlapping rights or penalties are accepted in other areas of the law. In the federal criminal law context, a defendant may be charged with multiple counts arising out of a single transaction. For example, in a drug case, if the defendant possessed a certain quantity of meth he could be charged with possession, possession for sale, and transportation. In Blockburger v. United States, 284 U.S. 299 (1932), the Supreme Court ruled the defendant's single act, the sale of narcotics, violated two sections of the statute, and, therefore, constituted the commission of two offenses. Id. at 304. The court used the following test, stating: "Each of the offenses ... requires proof of a different element. The applicable rule is that, where the same act or transaction constitutes a violation of two distinct statutory provisions, the test to be applied to determine whether there are two offense or only one is whether each provision requires proof of an additional fact which the other does not." Id. This is also the case with overlapping IP. Each statute requires different elements to qualify for the protection and different elements to take advantage of the rights granted through the right to exclude.

239. Now, some may argue that the IP Clause requiring enforcement of a limited term must be considered when dealing with the possibility of an indefinite term under the Trademark Act. The question becomes whether the patent or copyright is being extended indefinitely, or is the indefinite term applied to a different but related aspect of the design. I argue that the latter theory applies, rendering null any conflict with the IP Clause. 
Today, the Singer and Kellogg holdings do not and cannot stand for the broad proposition for which commentators often cite them; instead, these cases actually stand for the proposition that patented designs containing functional attributes pass to the public domain, in accordance with patent policy, upon patent expiration. Interpreting the Singer and Kellogg rulings as a right to copy subject matterwhether or not it was functional or nonfunctional, claimed or disclosed-renders virtually all forms of product designs ineligible for protection as trade dress. ${ }^{240}$ Such a broad ruling would be in direct conflict with the plain language of the Lanham Act and its legislative history. The legislative history states the twofold purpose of the Act as (1) protecting the public from confusion and deception in its purchasing decisions, and (2) ensuring the trademark owner that it, not pirates and cheats, reaps the benefit of energy, time, and money spent establishing the marks and associated products. This language would have no meaning under a per se bar, but finds meaning by balancing the right to copy against the right to compete based on need and as necessary to maintain a fair and ordered marketplace.

Just as a per se bar in the patent context goes too far, a per se bar in the copyright context also goes too far. The per se bar attempts to place creative designs and music in the public domain upon expiration of the copyright. As the proposed test demonstrates, there is room for creative designs and music to serve as source indicators without unlawfully extending copyright protections, as demonstrated with Gershwin's "Rhapsody in Blue," Betty Boop, and Steamboat Willie. The test considers how the design or music is used and whether the intended use is merely an attempt to extend copyright protection. As between the subject matter of an expired or existing copyright, the public's right to copy should yield to trademark law policy in protecting consumers from confusion, deceit, fraud, and mistake. ${ }^{241}$ This incursion on the public's right to copy is necessary to maintain a fair and orderly marketplace, with order and fairness being two of the central tenants of the natural law from which the right to copy originates.

Statutory interpretation also supports trademark protection for extant or expired copyright or patent protected designs. The rules of statutory interpretation require balancing the policy underlying the copyright, patent, and trademark statutes and interpreting each in a way that preserves harmony between them. The seemingly conflicting IP statutes are capable of coexisting because each provides different protections, imposes different requirements for receiving protection, provides different scopes of exclusion, and protects different attributes in the subject article.

Permitting overlapping and sequential IP trademark protection benefits consumers by preserving order in the common. It also benefits established companies as well as start-ups, affording each full protection under the U.S. IP laws. The time has come for the Supreme Court or Congress to formally overrule or overturn the per se bar of Singer and Kellogg and the progeny of copyright cases that support it.

240. See Rierson, supra note 49, at 737.

241. In re Mogen David Wine Corp., 328 F.2d 925, 933 (C.C.P.A. 1964) (Rich, J., concurring) (stating that in some instances "depriving the public of the right to copy [a design] is insignificant, as a policy matter, in comparison with the vendor's right to protection from possible confusion in trade"). 